\title{
Exploring How Human Activities Disturb the Balance of Biogeochemical Cycles: Evidence from the Carbon, Nitrogen and Hydrologic Cycles
}

\section{Olalekan Morufu Raimi $^{1^{*}}$ Abiola Ilesanmi $^{2}$ Ogah Alima $^{3}$ Dodeye E. Omini $^{4}$}

1. Department of Community Medicine, Environmental Health Unit, Faculty of Clinical Sciences, Niger Delta University, Wilberforce Island, Bayelsa State, Nigeria

2. Department of Plant and Environmental Biology, College of Pure and Applied Sciences, Kwara State University, Kwara State, Nigeria

3. School of Health and Life Sciences, Teesside University, Middlesbrough, United Kingdom

4. Faculty of Environment and Technology, University of the West of England, United Kingdom

\section{ARTICLE INFO}

Article history

Received: 24 June 2021

Accepted: 21 July 2021

Published Online: 31 July 2021

Keywords:

Biogeochemical cycles

Human activities

Worst disturbances

Ameliorative measures

\begin{abstract}
All around us today there is a clear evidence proof suggesting an observable influence by human on biogeochemical cycles which are likely to cause serious consequences for humanity. Activities of human affect the biogeochemical cycles, both directly as well as indirectly. If scholars were able to make clear the degree of how specific human actions are affecting the biogeochemical cycles, they (researchers) would be able to come up with ideas on how to better position toward suggesting strategies aimed at mitigating against disturbances that are worst. This paper aims at exploring how human activities affect the balance of biogeochemical cycles in relation to the Carbon, Nitrogen and Hydrologic Cycles. A literature analysis attempts to use a diversity of search engines such as Scopus, Researchgate, PubMed, Google Scholar, Summon, Hinari, CAB Abstract, OARE Abstract, Academia, Dimension, Mendeley, SSRN search strategy toward retrieving research publications, "grey literature" as well as expert reports from working group. This paper reviews some of the work done on this topic as well as locate the converging results of interest in all the studies as well as proffered solutions toward this menace with the purpose of forestalling future occurrence. Due to the actions of numerous human activities, the characteristics/features of several components of biogeochemical cycles are experiencing changes which are most likely led to long-term changes. It is essential to forecast the magnitude as well as degree of these changes so that the needed ameliorative actions could be originated well in time.
\end{abstract}

nature has transformed drastically. Currently, the term "human- dominated ecosystems" was associated agricultural fields with elicited images, pastures, or urban landscapes; it can now be applied to all the earth with greater or lesser force ${ }^{[1,2]}$. Directly, humanity dominated several ecosystems, as well as no earth's surface ecosystem is free

*Corresponding Author:

Olalekan Morufu Raimi,

Department of Community Medicine, Environmental Health Unit, Faculty of Clinical Sciences, Niger Delta University, Wilberforce Island, Bayelsa State, Nigeria;

Email: ola07038053786@gmail.com 
of pervasive human influence ${ }^{[3,4]}$. Interestingly, we don't just live on the Earth, but we change it. The Earth is a different place because of humans. We have changed the atmosphere, the seas and the surface of the land in many places through the activity of humans that have started to have a remarkable impact on the planet's climate and ecosystems and is characterized by massive global changes, including climate change, biodiversity loss, poverty, as well as food insecurity ${ }^{[5]}$. The challenge for society is to adapt to and mitigate these changes while transforming our systems, making them more efficient, inclusive, resilient and sustainable, for a better environment, and a better life, leaving no one behind. Thanks to us, some animals are much less common and others much more so. One of the things we have changed is the way that carbon is cycled. If we were to do something fairly common, such as go to the garage, fill our car up with fuel and use it to go for a day out, we have affected the carbon cycle. The fuel that we put in the car was made using oil, a fossil fuel. By using this we have reduced the amount of oil left. Driving the car involved burning the fuel. It used the process of combustion. This added to the amount of carbon dioxide in the atmosphere. In fact, simply by eating and breathing, we have moved carbon around its cycle. We have eaten food (which grew, or which are something that grew). This decreased the number of plants and we breathed out carbon dioxide ${ }^{[6,7]}$. The carbon cycle existed long before humans did of course, and there have been animals (and plants) respiring for millions of years before humans first walked on the surface of the Earth. In fact, for many years, people didn't affect the movement of carbon much. All that has changed in the last few hundred years. We have used up a huge amount of the available fossil fuels through burning them and this has released large volumes of carbon dioxide into the atmosphere ${ }^{[8]}$. These fuels have been used to provide transport, generate electricity and power factories to make things ${ }^{[9]}$. We have also changed the way that we use land. Large areas have been cleared of natural vegetation. The dense growth that has been removed stored much more carbon than the crops planted in their place. Not only have we added to the processes that produce carbon dioxide, but also, we have reduced the ways that it is removed. Looking at the carbon cycle, the way that carbon dioxide is removed from the atmosphere is by photosynthesis. Plants use carbon dioxide in the process of releasing energy from sunlight. If we grow, or allow to grow, fewer plants or smaller plants, their need for carbon dioxide is less.

Interestingly, man has become a powerful force now. $\mathrm{He}$ has tremendous power at his command. His actions have a global impact and has altered natural flora and fauna over a large surface area of the world ${ }^{[1-4,8]}$. Human establishments and agriculture are fast expanding as well as infringing on natural systems. Hill tops levelled, grasslands invaded, forests are cleared, marshes drained and even land under water is reclaimed to provide space for human establishments and his agriculture ${ }^{[1-4]}$. The soil is bared, natural ecosystems remain destroyed, flora as well as fauna exterminated and are replaced by such artificial systems as agriculture, horticulture, animal farms etc or else a jungle of steel and concrete structures comes up in place of high green vegetation. The two most important consequences of human activity are:

\section{i. Reduction in ecosystem complexity and diversity}

Humans remained over simplifying the structural complexities and diversity, which occur in undisturbed natural ecosystems. Agriculture, for example, is just an applied management of trophic chain. The complicated several tiered trophic natural system structures is been reduced to two links viz: Primary producer as well as human. Man sets an artificial agricultural system, protects the biomass ${ }^{[10-16]}$, which develops in his fields from pathogens insects, birds and other herbivores. All this increases the efficiency of production as the energy needed for maintenance of a simple structure is much lower than the complicated ones. However, simple trophic structures are more vulnerable to catastrophic changes. An unforeseen pathogen could reduce or eliminate the single species, which happens to constitute the entire population of producers. In a complicated ecosystem with each trophic level composed of a number of species, several alternatives are available for energy to flow, for materials to circulate in the system, which is thus maintained in operative state ${ }^{[17]}$. Man, also tends to oversimplify microbial community present in soils or water bodies. Use of chemical fertilizers and intensive agriculture lead to depletion of organic material on which microbial populations depend for nutrition which insecticides washed down into water and the soil kill susceptible organism directly ${ }^{[10-16]}$. Sewage, wastewater from industries and surface run-offs from agricultural fields pollute the aquatic systems in which susceptible organisms are suppressed ${ }^{[4,18,19]}$. Our soils not only provide food for the humanity but also regulate the operations of important biogeochemical cycles such as those of nitrogen, sulphur and carbon. Changes in microbial community within the soil on large scale affect its capacity to perform operations of these cycles effectively ${ }^{[17]}$.

The diversity of animal communities is also adversely affected by human activity. Man has taken a few species domesticated and protected them to form huge populations. Those species, which are left out, are finding it 
increasingly difficult to cope up with the stresses imposed by human activity around them. The overall effect of this is the replacement of diverse community with a community consisting of few species only which man chose to domesticate. This has led to a severely damaging effect on grasslands forests and has caused outbreak of animal diseases which have often acquired dimensions of an epidemic. The process of reduction in genetic diversity has also been taking place along with over simplification of natural ecosystems. A number of plants and animals have become extinct or are on verge of extinction. Evolution of new texa and extinction of ill adopted ones have been taking place in a balanced way ever since life came into existence. However, the strain placed by human activity has speeded up the process of elimination of weaker species. This is a sad state of affairs. Each extinct species takes away with it a combination of traits or gene pool, which took millions of years to evolve. The loss is irreparable ${ }^{[4,17]}$. To date about 150 species of plants are cultivated on large scale. Of these 150 species, only $29 \%$ provide the total food stock available to the humanity. Man has slowly and consciously been reducing the number of plants and animals, which he breeds. Selection of varieties for better output, resistance to the environmental conditions, better tastes and flavours etc has led to a drastic reduction in genetic diversity of plants and animals. The varieties or species in which he is no longer interested are vanishing one after the other. The decreased genetic diversity of plants cultivated on large-scale places restrictions on the possibilities of creating new varieties through breeding programs. Growing genetically uniform plants or livestock is their increased vulnerability to unkind environment or unforeseen pathogens.

\section{ii. Changes in biogeochemical cycles}

Ruthless exploitation and pollution of the environment has disturbed the operation of all-important biogeochemical cycles. The magnitude of waste materials has been growing persistently. Those waste or their decomposition products are regularly added to the various components of the environment in significant quantities to disturb even the global cycles. Man has been extracting substantial quantities of material which represent biological output of pass ages, at a rate much faster than the rate of their formation. So are the deposits of various minerals elements and metal formed by persistent biogeochemical activity of millions of years, which are being depleted at a very fast rate. These resources belong to our children and grandchildren as much as they do to us ${ }^{[3]}$. The policy of reckless exploitation of natural resources is one which our future generation will rightly deplore. atmosphere, land and oceans and to the mass movements of air around the planet. The earth contains about $10^{23} \mathrm{~g}$ of carbon. All but a small fraction is buried in sedimentary rocks and is not actively involved in the global carbon cycle. The carbon pool involved in the global carbon cycle (Figure $1 \mathrm{a}, \mathrm{b} \& \mathrm{c}$ ) amounts to an estimated $55 \times 10^{18} \mathrm{~g}$ or $55,000 \mathrm{Gt}$ ( $\mathrm{Gt}$ is a gigaton, equal to 1 billion [10 $]$ metric tons or $10^{15} \mathrm{~g}$ ). Fossil fuels, created by the burial of partially decomposed organic matter, account for an estimated $10,000 \mathrm{Gt}$. The oceans contain the vast majority of the active carbon pool, about 38,000 Gt, mostly as bicarbonate ions $\left(\mathrm{HCO}_{3}{ }^{-}\right)$and carbonate ions $\left(\mathrm{CO}_{3}{ }^{-}\right)^{[32]}$. Dead organic matter in the ocean's accounts for $1650 \mathrm{Gt}$ of carbon, and living matter, mostly phytoplankton, $3 \mathrm{Gt}$.

In addition, the study of nature-based solutions frequently places emphases on the amount of carbon they could take away from the atmosphere. A novel study examines how these solutions adaptation strategies affect global temperatures, an important measure as humanity tries to control global warming. It was suggested that an eco-nature-based strategy may perhaps decrease peak warming through an additional $0.3^{\circ} \mathrm{C}$ beneath a scenario in agreements with a $2^{\circ} \mathrm{C}$ general temperature rise come 2085. Cécile Girardin, a climate-change policy analyst as well as seven other contemporaries clarify in what way environmental related projects that is managed, protected as well as restore ecosystems may perhaps offer climate, biodiversity as well as socio-economic benefits, if done correctly, and rapidly. Hence, the terrestrial biosphere contains an estimated $1500 \mathrm{Gt}$ of carbon as dead organic matter and $500 \mathrm{Gt}$ as living matter (biomass). The atmosphere, the major coupling mechanism in the cycling of $\mathrm{CO}_{2}$, holds about $750 \mathrm{Gt}$ of carbon ${ }^{[21,22]}$. In the ocean, the surface water acts as the site of main exchange of carbon between atmosphere and ocean. The ability of the surface waters to take up $\mathrm{CO}_{2}$ is governed largely by the reaction of $\mathrm{CO}_{2}$ with the carbonate ion to form bicarbonates. In the surface water, carbon circulates physically by means of currents and biologically through assimilation by phytoplankton and movement through the food chain. The next exchange of $\mathrm{CO}_{2}$ between the oceans and atmosphere due to both physical and biological processes result in a net uptake of $2 \mathrm{Gt}$ per year by the oceans, while burial in sediments accounts for a net loss of $0.1 \mathrm{Gt}$ of carbon per year. The uptake of $\mathrm{CO}_{2}$ from the atmosphere by terrestrial ecosystems is governed by gross production (photosynthesis). Losses are a function of autotrophic 


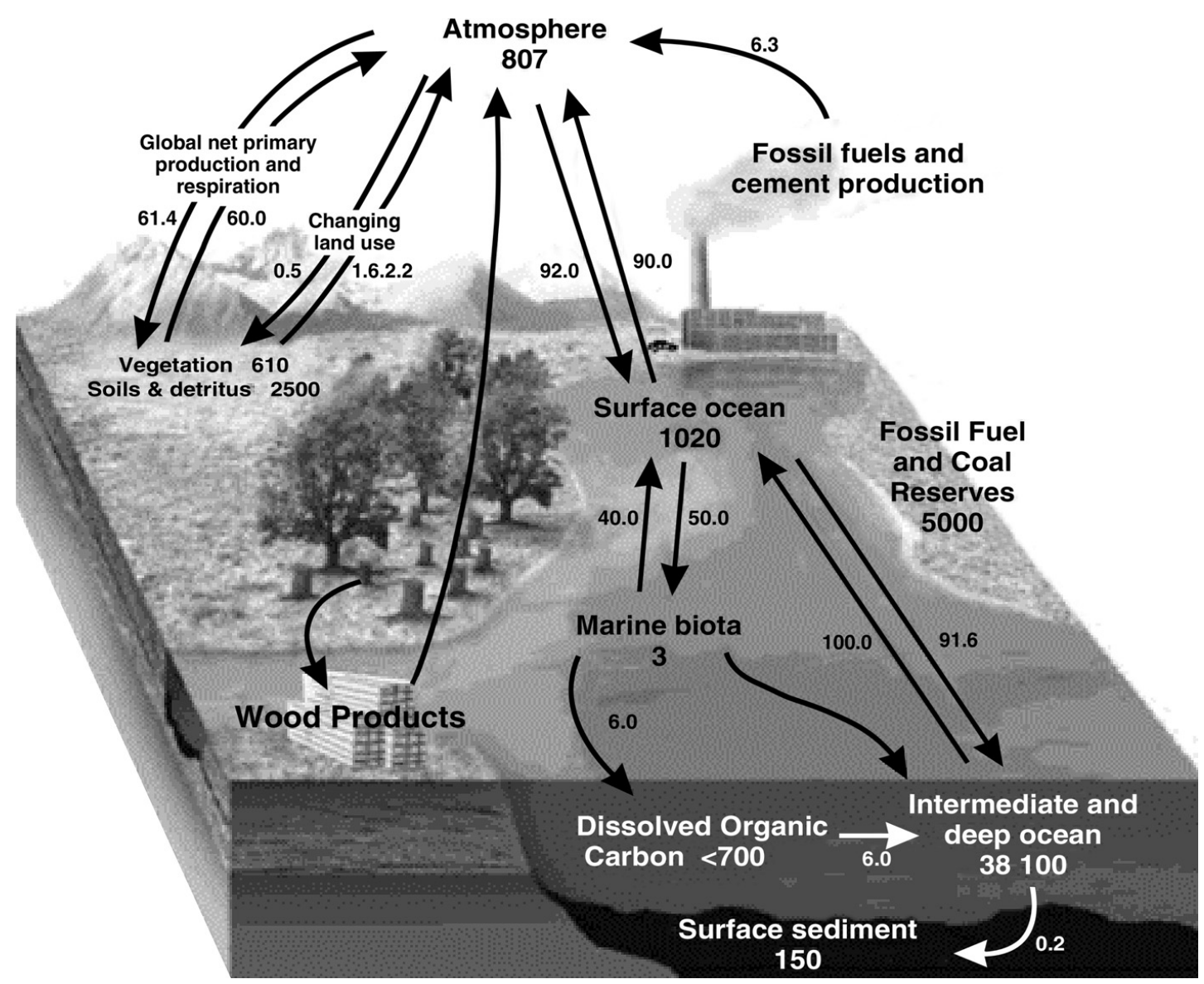

\section{Natural Capital: Carbon Cycle with Major Harmful Impacts of Human Activities}

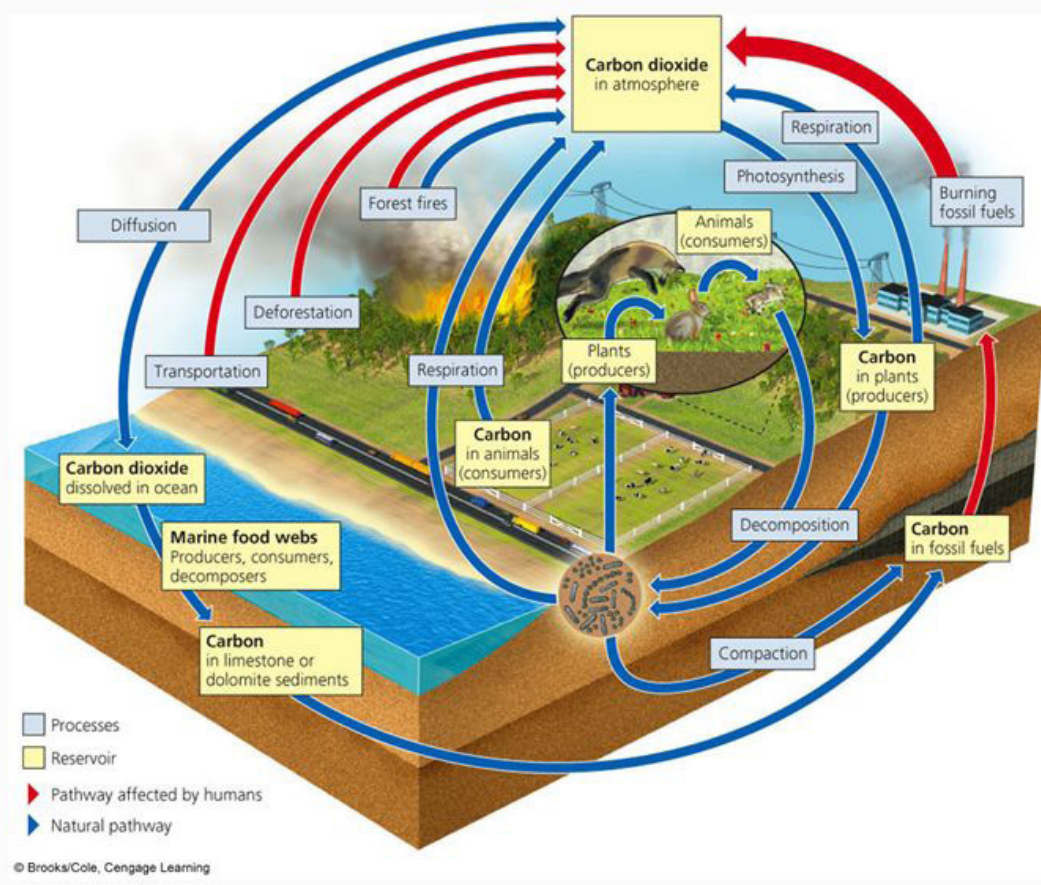




\section{THREE STEPS TO NATURAL COOLING}

Protect intact ecosystems, manage working lands and restore native cover to avoid emissions and enhance carbon sinks.

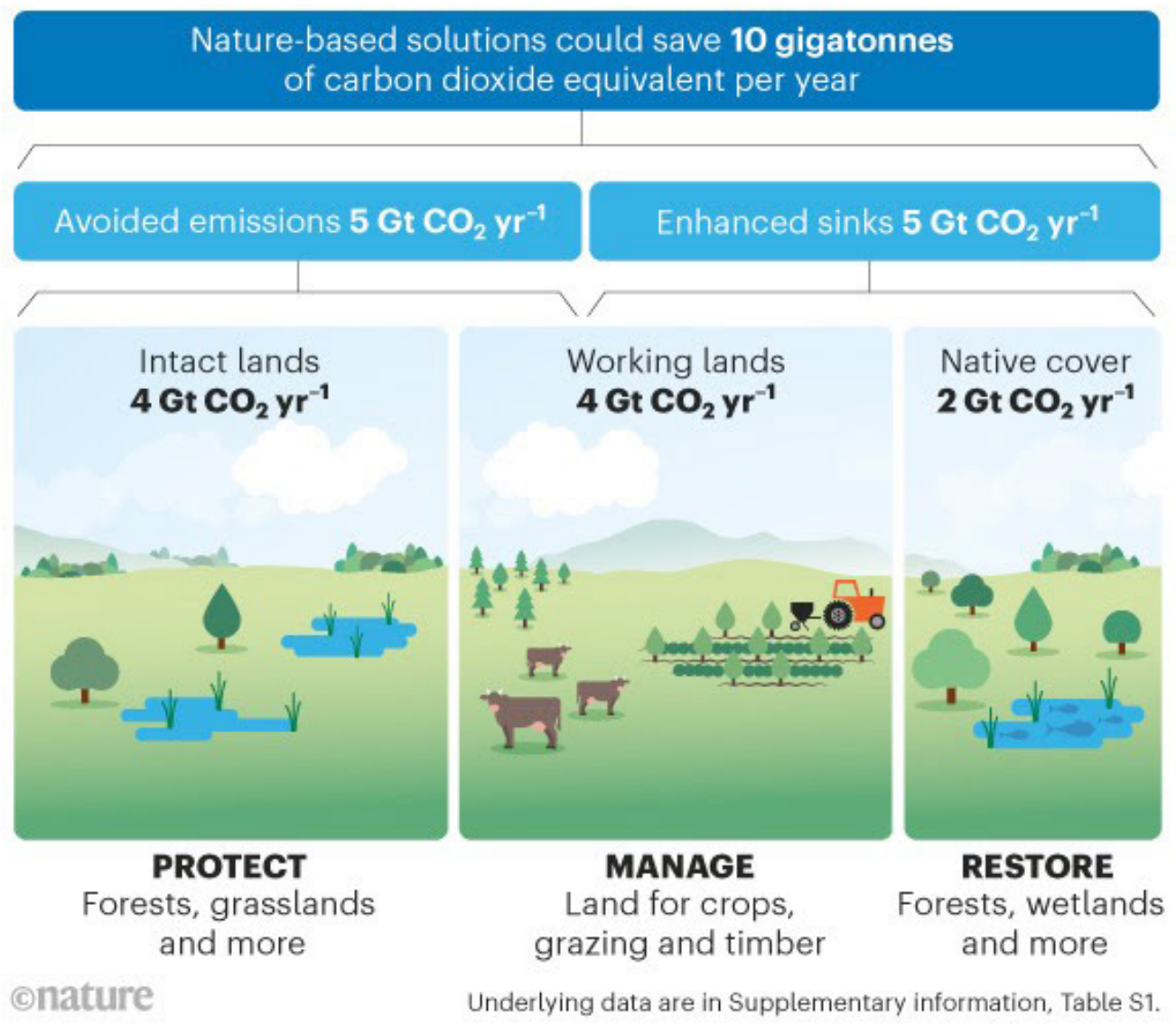

Figure 1a, b \& c. Overview of the global carbon cycle. The stocks and fluxes of $\mathrm{C}(\mathrm{Gt})$ between various components and the atmosphere. Modified from Bhatti et al. ${ }^{[20]}$

Source: https://mail.google.com/mail/u/0/\#inbox/FMfcgxwLttCBqCxzgtBhJLZNHRRHvMhQ.

and heterotrophic respiration; the latter being dominated by microbial decomposers. Until recently, exchanges of $\mathrm{CO}_{2}$ between the land mass and the atmosphere (uptake in photosynthesis and release by respiration/decomposition) were believed to be nearly in equilibrium. However, more recent research suggests that the terrestrial surface is acting as a carbon sink, with a net uptake of $\mathrm{CO}_{2}$ from the atmosphere $^{[22]}$.

Of considerable importance in the terrestrial carbon cycle is the relative proportions of carbon stored in soils and in living vegetation (biomass). Carbon stored in soils includes dead organic matter on the soil surface and in the underlying mineral soil. Estimates place the amount of soil carbon at $1500 \mathrm{Gt}$, compared with $560 \mathrm{Gt}$ for the total world terrestrial biomass. Much of this carbon stored as dead organic matter is in the lower soil profile, where it exceeds carbon in the surface soil by a factor of 25 .
The lower soil layers of tropical forests and both tropical and temperate grasslands contain a large percentage of soil carbon, whereas soil carbon in temperate forests and Arctic regions is confined largely to the surface soil layers. The average amount of carbon per unit of soil profile increases from the tropical regions poleward to the boreal forest and tundra (Table 1). Low values for the tropical forest reflect high rates of decomposition, which compensate for high productivity and litterfall. Frozen tundra soil and waterlogged soils of swamps and marshes have the greatest accumulation of dead organic matter, because moisture, low temperature, or both inhibit decay. Soil carbon greatly exceeds biomass in boreal forests and tundra. Soil carbon likewise exceeds biomass in temperate grasslands, but in tropical savannas the reverse situation exists, probably because of recurring fires. World output of carbon from respiration resulting from the decompo- 
sition of soil carbon in terrestrial ecosystems amounts to approximately $60 \mathrm{Gt}$ per year.

The global cycle of atmospheric carbon dioxide, like local cycles, exhibits a marked annual variation, particularly in the land-dominated Northern Hemisphere. North of the $30^{\circ} \mathrm{N}$ latitude, carbon dioxide content of the atmosphere up to the lower stratosphere begins to decline markedly during early spring, when photosynthetic activity and carbon storage in plant growth withdraw more carbon dioxide from the atmosphere than is replaced by respiration. The concentration of carbon dioxide reaches a low in August. By October the level increases again as photosynthesis declines and respiration dominates the exchange between the atmosphere and terrestrial ecosystems. The difference in the magnitude of the seasonal oscillation of $\mathrm{CO}_{2}$ between the Northern and Southern Hemispheres reflects the difference in the land mass of the two hemispheres.

\subsection{Human impact on the carbon cycle}

The $\mathrm{CO}_{2}$ flux among land, sea and atmosphere has been disturbed by a rapid injection of carbon dioxide in the atmosphere from the burning of fossil fuels and from the clearing of forests ${ }^{[1-3]}$. Clearing increases the input of $\mathrm{CO}_{2}$ from burning trees and decomposing organic matter ${ }^{[3,8]}$. Adding to the problem of increasing carbon dioxide are increases in other atmospheric gases, especially methane $\left(\mathrm{CH}_{4}\right)$. Its major sources are ruminant animals, microbial decomposition in swamps, marshes and tun- dra and industrial gases released to the atmosphere ${ }^{[24-27]}$. Over time (resident time of 3.2 years) methane oxidizes to $\mathrm{H}_{2} \mathrm{O}$, especially in the stratosphere. Atmospheric methane has approximately doubled over the past 200 years. This increase is linked to human population growth and to increased cattle ranching and rice paddy production. The rising atmospheric concentrations to $\mathrm{CO}_{2}$ and methane have the potential to alter the global energy balance and subsequently the global climate system. The implication of rising atmospheric concentrations of $\mathrm{CO}_{2}$ and possible climate change ${ }^{[6,7,27]}$. Human activity has led to an enhanced rate of output of carbon into the atmosphere which has caused a measurable rise in the concentration of atmospheric $\mathrm{CO}_{2}$. This is due to increased use of organic matter, coal, petroleum and natural gas as fuel and the combustion of carbonate rocks for the manufacture of cement and lime ${ }^{[28]}$. Rapidly growing human population is also modifying the natural ecosystems over an increasingly larger area of earth's surface by extensive deforestation, faulty agricultural practices, intensive grazing etc ${ }^{[1-3,8]}$. The universally distributed poisons like lead and DDT tend to depress the photosynthesis efficiency of green plants on global scale. So, while there are more inputs of $\mathrm{CO}_{2}$ in the atmosphere its output is somewhat reduced. We have a little more than $5500 \times 10^{9}$ metric tons of carbon locked in fossil fuels, which represent photosynthesis of past ages. Today about $835 \times 10^{9}$ metric tons of carbon is locked in the biosphere and the atmosphere contains about $725 \times 10^{9}$ metric tons of carbon as $\mathrm{CO}_{2}$. No wonder between the years $1880 \mathrm{AD}$

Table 1. Distribution of Detritus and Biomass by Ecosystem Types

\begin{tabular}{|c|c|c|c|c|c|}
\hline Ecosystem Type & $\begin{array}{l}\text { Mean Total Profile } \\
\text { Detritus }\left(\mathrm{kg} \mathrm{C} / \mathrm{m}^{2}\right)\end{array}$ & $\mathrm{CV}(\%)$ & World Area $\left(10^{9} \mathrm{ha}\right)$ & $\begin{array}{c}\text { Total World Detritus }\left(10^{9}\right. \\
\text { mtn C) }\end{array}$ & $\begin{array}{l}\text { Total World Biomass } \\
\qquad\left(10^{9} \mathrm{mtn} \mathrm{C}\right)\end{array}$ \\
\hline Woodland and shrubland & 6.9 & 59 & 8.5 & 59 & 22.0 \\
\hline Tropical savanna & 3.7 & 87 & 15.0 & 56 & 27.0 \\
\hline Tropical forest & 10.4 & 44 & 24.5 & 255 & 460.0 \\
\hline Temperate forest & 11.8 & 35 & 12.0 & 142 & 175.0 \\
\hline Boreal forest & 14.9 & 53 & 12.0 & 179 & 108.0 \\
\hline Temperate grassland & 19.2 & 25 & 9.0 & 173 & 6.3 \\
\hline Tundra and alpine & 21.6 & 68 & 8.0 & 173 & 2.4 \\
\hline Desert scrub & 5.6 & 38 & 18.0 & 101 & 5.4 \\
\hline Extreme desert & 0.1 & - & 24.0 & 3 & 0.2 \\
\hline Cultivated land & 12.7 & - & 14.0 & 178 & 7.0 \\
\hline Swamp and march & 68.6 & 63 & 2.0 & 137 & 13.6 \\
\hline Total & & & 147.0 & 1456 & 826.9 \\
\hline
\end{tabular}

$\mathrm{CV}=$ coefficient of variation $=$ standard deviation $/$ mean $\mathrm{x} 100$

Source: Adapted from Schlesinger ${ }^{[23]}$ 
to $1960 \mathrm{AD}$ the total mass of carbon in earth's atmosphere rose by $12.14 \%$ of which about $150 \times 10^{9}$ metric tons has been introduced as a result of burning of fossil fuel alone.

\section{Global Nitrogen Cycle}

\subsection{Main features}

The global nitrogen cycle follows the pathway of the local nitrogen cycle, only on a grander scale. The global cycle is diagrammed in Figure 2. The atmosphere is the largest pool, containing $3.9 \times 10^{21} \mathrm{~g}$. Comparatively small amounts of nitrogen are found in the biomass $\left(3.5-10^{15} \mathrm{~g}\right)$ of terrestrial ecosystems ${ }^{[29,30]}$. The major sources of fixed nitrogen are biological (140 x $\left.1012 \mathrm{~g} \mathrm{yr}^{-1}\right)$ and high-energy fixation of atmospheric nitrogen by lightning $>3 \times 10^{12} \mathrm{~g}$ $\left.\mathrm{yr}^{-1}\right)^{[31,20]}$. Additional sources of nitrogen include inorganic nitrogen in rain, from such sources as fixed juvenile nitrogen from volcanic activity; absorption of ammonia from the atmosphere by plants and soil; and nitrogen accretion from windblown aerosols, which contain both organic and inorganic forms of nitrogen. In terrestrial ecosystems, ammonia and nitrates are taken up by plants and converted to organic nitrogen (amino acids) and moved through the food chain ${ }^{[31,20]}$. Dead organic matter is broken down into ammonia, then into nitrates and nitrites. Nitrates may be taken up directly by plants, immobilized by microbes, stored in decomposing humus, or leached into streams, lakes, and eventually seas. The uptake of inorganic nitrogen by plants is so rapid that at any given time, the pool of inorganic nitrogen $\left(\mathrm{NH}_{4}^{+}\right.$and $\left.\mathrm{NO}_{3}^{-}\right)$in soils is very small. Most of the nitrogen stored in terrestrial ecosystems is tied up in organic matter, both living and dead ${ }^{[31]}$. Global estimates of denitrification in terrestrial ecosystems vary widely but are on the order of $<200 \times 10^{12} \mathrm{~g} \mathrm{yr}^{-1}$, of which over half occurs in wetland ecosystems ${ }^{[29]}$. The major sources of nitrogen to the world's oceans are dissolved forms in the freshwater drainage from rivers $\left(36 \times 10^{12} \mathrm{~g}\right.$ $\left.\mathrm{yr}^{-1}\right)$ and inputs in precipitation $\left(30 \times 10^{12} \mathrm{~g} \mathrm{yr}^{-1}\right)^{[33]}$. Biological fixation accounts for another $15 \times 10^{12} \mathrm{~g} \mathrm{yr}^{-1}{ }^{[31]}$. In aquatic ecosystems, nitrogen is cycled internally in a similar manner to that discussed for terrestrial ecosystems, except that the large reserves, such as those contained in soil humus, are lacking. Life in the water contributes organic matter and dead organisms that undergo decomposition and subsequent release of ammonia and nitrates.

Tracer studies with ${ }^{15} \mathrm{~N}$, a stable, nonradioactive isotope, show that in marine ecosystems, ammonia is recycled rapidly by phytoplankton ${ }^{[31]}$. As a result, little ammonia exists in natural waters, and nitrates is used only in the virtual absence of ammonia. There are small but steady

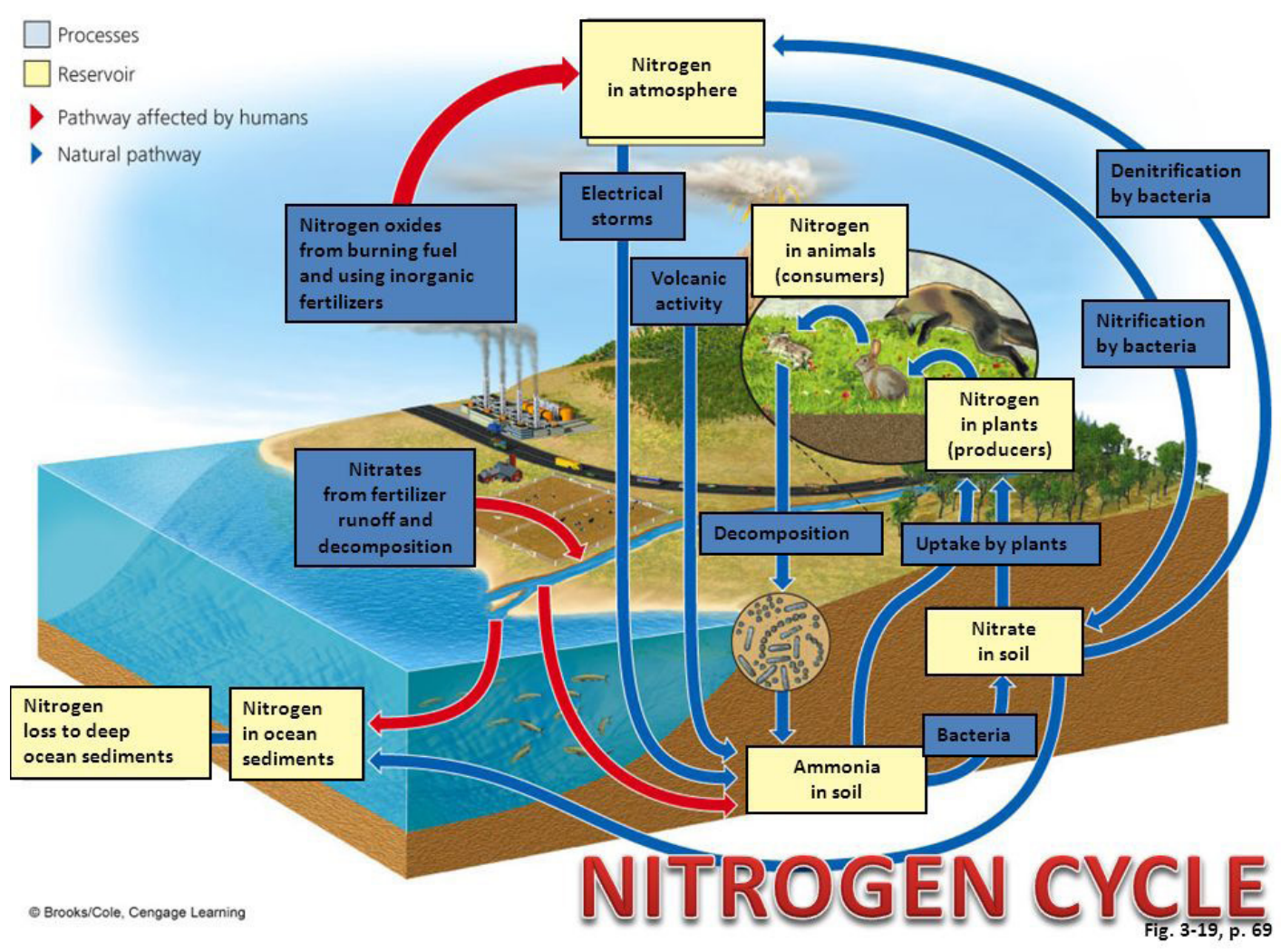

Figure 2. Overview of the global Nitrogen cycle. 
losses from the biosphere to the deep sediments of the ocean and to sedimentary rocks. In return there is a small addition of new nitrogen from the weathering of igneous rocks and juvenile nitrogen from volcanic activity. Denitrification accounts for an estimated flux of $110 \times 10^{12} \mathrm{~g} \mathrm{~N}$ $\mathrm{yr}^{-1}$ from the world's oceans to the atmosphere.

\subsection{Human impact on the nitrogen cycle}

Under different circumstances, human intrusions into the nitrogen cycle result in either a reduction on an increase in nitrogen availability. Conversion of forests and grasslands to cropland results in a steady decline in nitrogen content of the soil. Mixing and breaking up the soil exposes more organic matter to rapid decomposition and leaching from the soil. Removal of nitrogen through harvested crops and grazing causes additional losses. On the other hand, excessive amounts of nitrogen may be added to the system, creating a variety of problems. Heavy applications of commercial fertilizer disturb the natural balance between fixation and denitrification by reducing the former and increasing the latter. A considerable portion of the added nitrogen may be leached to the groundwater as nitrates ${ }^{[18,34-36]}$. Animal wastes, especially from livestock concentrated in large feedlots, are another source of nitrates in groundwater. Excessive quantities of nitrates in groundwater become health endangering pollutants ${ }^{[18,34-36]}$.

A third source of nitrate pollution is human waste, particularly sewage, treated or otherwise, released into rivers, lakes and estuaries ${ }^{[37]}$. In spite of the magnitude of water pollution from agricultural sources, human effluents contribute even heavier loads, especially from municipal sewage treatment. Automobiles and power plants are the major sources of nitrogenous pollutants in the atmosphere, particularly nitrogen oxides ${ }^{[9,38]}$. Current estimates place nitrogen emissions due to automobiles, factories, power plants and other combustion processes at $20 \times 10^{12} \mathrm{~g} \mathrm{~N} \mathrm{yr}^{-1}$. The primary nitrogenous air pollutant is nitrogen dioxide $\left(\mathrm{NO}_{2}\right)$, a pungent gas that produces a brownish haze. In the atmosphere, nitrogen dioxide is reduced by ultraviolet light to nitrogen monoxide and atomic oxygen:

$\mathrm{NO}_{2}$

$$
\mathrm{NO}+\mathrm{O}
$$

Atomic oxygen reacts with molecular oxygen to form ozone:

$\mathrm{O}_{2}+\mathrm{O}$

$\mathrm{O}_{3}$

Ozone, in a never-ending cycle, reacts with nitrogen monoxide to form nitrogen dioxide and oxygen:

$\mathrm{NO}_{2}+\mathrm{O}_{3} \quad \mathrm{NO}_{2}+\mathrm{O}_{2} \longrightarrow$

This cycle illustrates only a few of the reactions that nitrogen oxides undergo or trigger. In the presence of sunlight, atomic oxygen from nitrogen dioxide also reacts with a number of reactive hydrocarbons to form radicals. These radicals then take part in a series of reactions to form still more radicals that combine with oxygen, hydrocarbons, and nitrogen dioxide. As a result, nitrogen dioxide is regenerated, nitrogen monoxide disappears, ozone accumulates and a number of secondary pollutants form, including formaldehydes, aldehydes, and peroxyacylnitrates, known as PAN. All of these pollutants especially PAN, and ozone are very toxic and injury many forms of plant life exposed to them. One outcome of nitrogenous atmospheric pollution is an increased deposition of nitrogen, which benefits ecosystems that are traditionally nitrogen-limited, especially northern and high-altitude forests. Such ecosystems, however, can suffer from too much of a good thing. Because under natural conditions nitrogen is limiting, these forests are efficient at retaining and recycling nitrogen from precipitation and organic matter. Significant export of nitrates to stream is seldom seen. However, many of these forests are receiving more nitrogen in the form of ammonium and nitrates than the trees and their associated microbial populations can handle and accumulated, a condition referred to as nitrogen saturation. Under these conditions, excess nitrogen, particularly in the form of nitrate, leached into surface waters.

The first response to increased availability of nitrogen in a nitrogen-limited ecosystem is increased growth of both canopy and stems. Evidence suggests, however, that increased levels of nitrogen can lead to the decline and dieback of coniferous forests at high elevations ${ }^{[20]}$. If the increased growth in foliage continues into late summer, the late new growth may not have time to become frost-hardened and is killed during the winter. Overstimulated by nitrogen, tree growth exceeds the availability of other necessary nutrient in the soil, particularly phosphorus, and the tree begins to experience nutrients deficiencies. Experimental evidence suggests that the production of fine roots and ectomycorrhiza, which take up nutrient deficiencies. Experimental evidence suggests that the production of fine roots and ectomycorrhiza, which take up nutrients from the soil, is lower on sites rich in nutrients, especially nitrogen, than in nutrient-poor soils, and root turnover is higher. Trees on nutrient -poor soil have a longer-lived and higher density root system and a lower turnover of root biomass. These conditions help the trees to scavenge nutrients from poor soils. As nitrogen levels increase, root biomass decreases because sufficient nitrogen is nearby. A smaller root biomass then inhibits the uptake of nutrients other than nitrogen and impairs the ability of tress to pull water from then soil during periods of drought. As nitrogen deposition increases, ammonium levels in the soil increase. Excess ammonium in the soil 
stimulates nitrification, denitrification, and mobility of nitrates in the soil, even at a low $\mathrm{pH}$. As excess nitrates are leached from the soil, they increase anion movement through the soil, releasing aluminium $\left(\mathrm{AI}^{3+}\right)$ As has been observed in the spruce stands of the Great Smoky Mountains. This aluminium finds its way to aquatic ecosystems, increasing their acidification.

\section{Hydrological Cycle}

\subsection{Main features}

Figure $3 \mathrm{a} \& \mathrm{~b}$ represents a conceptual model of the hydrologic cycle and shows Earth's water movement between the ocean, land, and atmosphere. As with all cycles, it is ongoing and continuous, and there is no specific start or end point. Precipitation is water released from the atmosphere in the form of rain, snow, sleet or hail. During precipitation, some of the moisture is evaporated back into the atmosphere before ever reaching the ground. Some precipitation is intercepted by plants, a portion infiltrates the ground, and the remainder flows off the land into lakes, rivers, or oceans. An important difference between the roles of snow and rain is that runoff occurs relatively quickly following the rain event, whereas snow usually melts much more slowly over days, weeks, or months. The subsequent surge of snowmelt runoff can provide seasonal recharge to groundwater resources but can also trigger flood conditions if the snowmelt occurs too rapidly and in excessive amounts ${ }^{[39]}$. In addition, the solid snow or ice may change directly into a gas, skipping the liquid state, in the process called sublimation. When precipitation is intercepted by plants, it is eventually evaporated back to the atmosphere. When it infiltrates the ground, it can be taken up by roots and transpired by plants, it can be evaporated from the soil, or it may recharge an aquifer.

The water in an aquifer is called groundwater, and its rate of flow in the subsurface is such that water can reside in aquifers for days to centuries before discharging to a surface body of water (e.g., river, lake, and ocean). Once groundwater has been discharged into a river, lake, or ocean, the surface of the water body is exposed for evaporation, causing moisture to collect and concentrate in the atmosphere, eventually returning to the earth as precipitation as the cycle begins again. In addition to natural discharge, groundwater can more rapidly discharge when an aquifer is pumped. With the advent of motorized pumps, the rapid removal of groundwater from aquifers is a relatively recent phenomenon that has greatly affected the depletion of the aquifers and the water balance of many catchments ${ }^{[33]}$.

Despite the fact, the hydrological cycle is a continuous process. It is by no means universal all over the globe: the water residence time differs repeatedly dramatically between diverse cycle of portions. For instance, water is uninterruptedly evaporated from the surface of water bodies (e.g., oceans, lakes, as well as rivers). Likewise, rainfall that is interrupted through plants as well as other surfaces is frequently evaporated within hours. After evaporation, an average of 10 days is taken for a water molecule to go round the atmosphere, but if it infiltrates to the water table, or if the precipitation occurs in a polar region, it can take decade of years before transferring to another phase next in the water hydrologic cycle. Besides the variable residence periods, the processes related to the hydrologic cycle are not distributed evenly over the earth; they differ in climatic region ${ }^{[33]}$. For instance, rapid evapotranspiration can occur in semi-arid and arid areas. Nonetheless successive rainfall might not happen within the same region or basin. The dramatic changes in how the cycle operates are particularly evident as soon as the hydrologic cycle is evaluated at the level of catchment scale.

\subsection{Human impact on the hydrological cycle}

The past human activity interaction, including hydrological balance, has led to the exploitation of irrigation systems, as well as in the contemporary urbanization period. Irrigation systems of this kind, using water from stream network as well as larger canals systems have become characteristic of India great hydraulic societies ${ }^{[33]}$. But then again, the population pressures as well as industry on urbanization over the past three years has led to the irrigation demand extension as well as water services in novel areas. This often seems to lead toward integration of isolated system in the drainage basin. Activity of humans has disrupted all parts of the water cycle; runoff is deposited in huge reservoirs behind dams, transpiration losses reduced through deforestation, groundwater is filled with water spreading as well as pumping. Human activity impact in Table 1 shows diverse major basins drainage in South India as well as their hydrogeological and hydrological features. The unplanned pattern of irrigation as well as past agricultural methods in South India have made effective management of water very difficult. Large shallow tanks previously built remain at the moment being silted up rendering irrigation useless. Canals losses through seepage as well as drains remain heavy. Most South India wells, dug in the hard rock zones, are mostly shallow (There are tube wells in soft alluvium in riverine areas). The depth, diameter as well as large wells spacing have not yet been methodically studied for optimum utilization. The South India irrigation wells collapsed due to a rising depression cone in water table. Because of these water management shortcomings through human agency, 


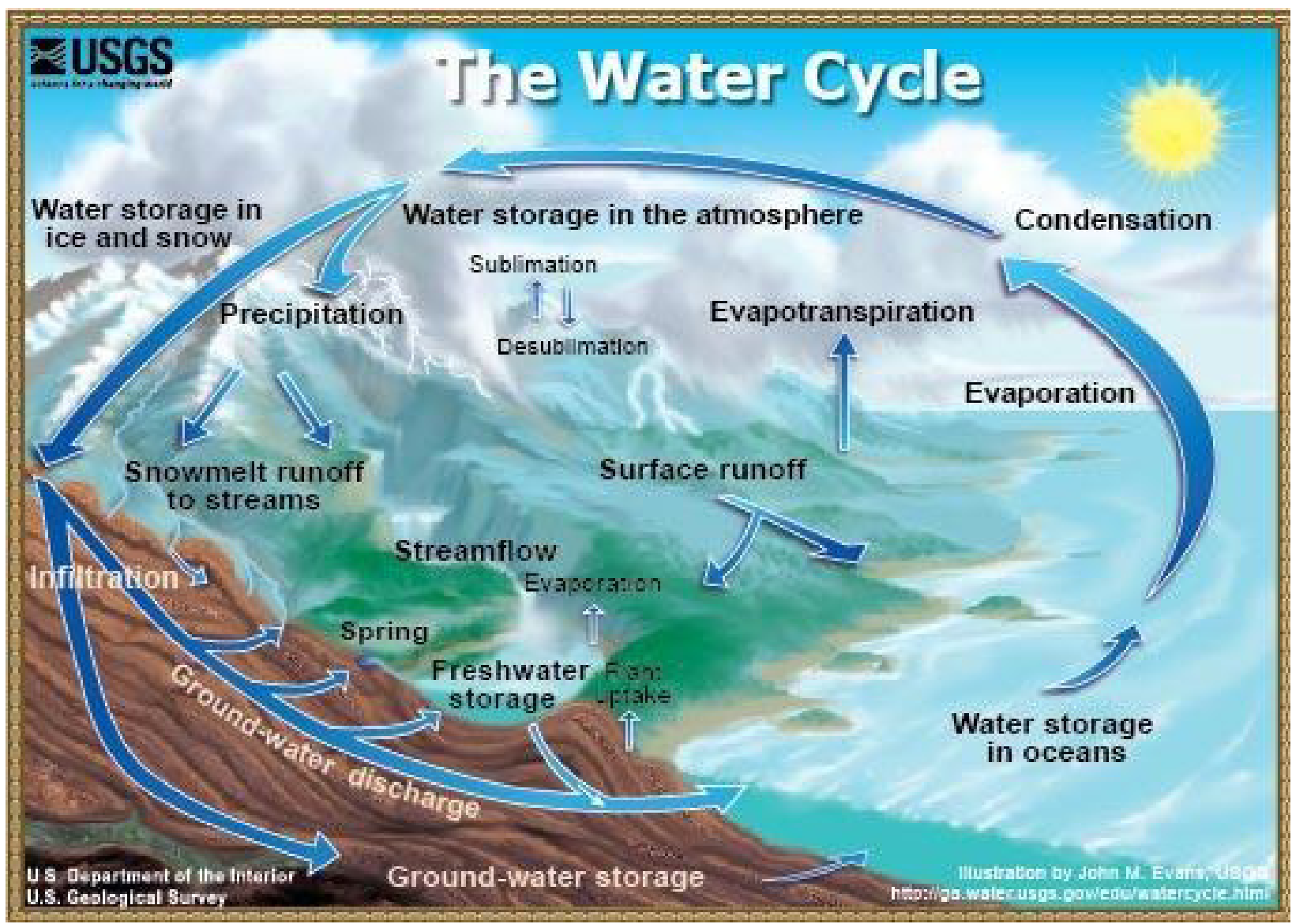

\section{Hydrologic Cycle Including Harmful Impacts of Human Activities}

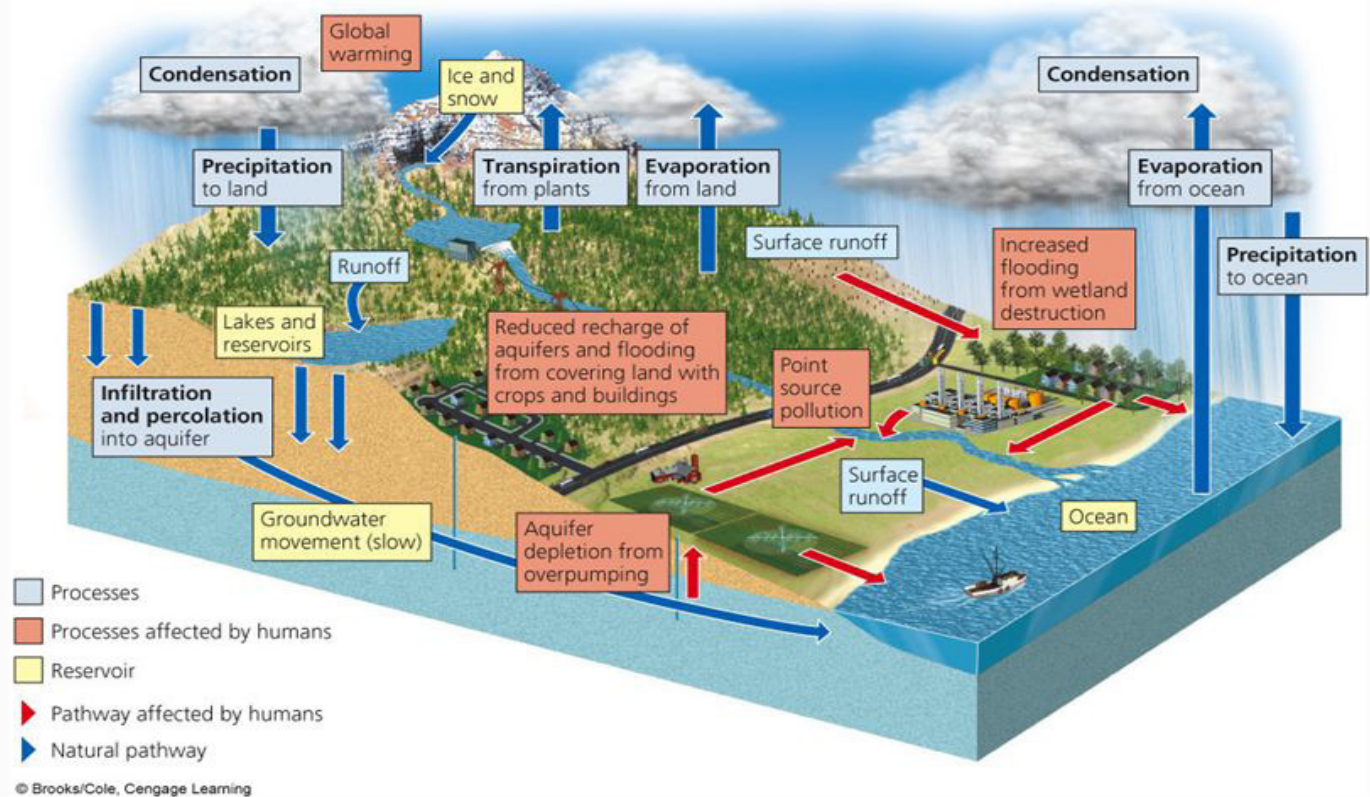

Figure 3a \& b. Schematic representation of the hydrologic cycle. (USGS) 
various parts of the interior of South India are frequently drought as well as famine stricken. There are various rural areas where individuals have to travel several miles for water. A systematic future development plan for water resources in South India is instantly obligatory toward ensuring adequate supplies.

\subsection{Global hydrological cycle}

Earth's majority water (approximately 1.4 billion cubic meters or $96.5 \%$ of all resources) is found in oceans. Continental water accounts for approximately $3.5 \%$ of world's water supply; nevertheless, approximately three-quarters of that percentage (29 million cubic kilometers) exists as polar ice caps as well as glaciers, and deep groundwater is approximately 5.3 million cubic kilometers. Hence, only other fractions can enter the water exchange amongst the atmosphere, oceans, as well as the continents. This residue part comprises deep groundwater as well as soil moisture (approximately 4.3 million cubic kilometers); water from reservoirs, lakes, as well as swamps $(0.125$ million cubic kilometers); storage of water in river channels (2.1 thousand cubic kilometers); water from biosphere (approximately 0.6 thousand cubic kilometers). The atmospheric amount is only 0.013 million cubic kilometers $(0.001 \%)$. The main global mechanisms as well as terrestrial water cycles remain the water exchange amongst the atmosphere as well as the oceans, the earth's surface and amongst continents. The most important sources of energy exchange today are solar radiation as well as gravitational force. Yearly, the earth's surface disperses water, approximately 580,000 cubic kilometers. The required energy toward converting this sum of water into steam vapor matches up to $36 \%$ of solar energy absorbed through the entire earth. Approximately $85 \%$ of the total world-wide evaporation comes from the surface of the ocean as well as the rest comes from the evaporation of the land surface. The average yearly moisture content on the surface ocean unit area is $1400 \mathrm{~mm}$; moreover, this land surface value is only 485 $\mathrm{mm}$ (roughly three times lower). Averagely, evaporating water stays in the atmosphere for approximately $8-10$ days, due to air moisture condensation, majority of the dispersed water falls back to the earth's surface as snow or rain. The total yearly rainfall on the surface of the earth's is roughly proportional to the whole global evaporation. Nevertheless, the total yearly ocean surface evaporation is greater than the amount of rainfall. The evaporated water surplus (approximately 47,000 cubic kilometers) is carried through air currents resulting from oceans to continents [33]. Approximately $40 \%$ of the continent's rainfall returned to the oceans as river runoff (roughly 450,000 cubic kilometers), or groundwater that flows directly into the oceans (around 20,000 cubic kilometers). The rest reevaporates as well as returned to the ground. On average, transported water from the oceans is recycled as well as precipitated 2.7 times ashore before returning back to oceans.

\subsection{Human influence on the terrestrial hydrological cycle}

Activities of human alter the river basins land cover as well as remain intended at regulating fluxes of water in nature, which can significantly transform the water cycle of a separate river basins, as well as large regions. An outstanding instance of this modification is the current circumstances in Aral Sea basin, where thorough irrigation has occasioned in virtually complete water inflow cessation that cross the Syr-Darya River as well as the Amu-Darya River, along with drastic drop in sea level from the Aral. Other well-documented illustrations consist of risks of increased drought in the Mediterranean as well as the Sahel, following vegetation removal through deforestation as well as corresponding over exploitation. There is likewise indications that significant scale of change as well as flooding frequency in the Ganges basin might remain described through forest clearing in the rural mountainous area. Due to the activities of human, the natural river basins water cycle is becoming increasingly transformed as well as regimented. The major regulation methods of stream flow are dams, barrages, levees, as well as dikes construction, which offer accumulation of water, increasing low flow, as well as flood flow decrease. The main impact on the construction reservoir on water cycle (except runoff control) is to increase evaporation as well as groundwater table rise. In arid areas, losses resulting from evaporation of reservoir water surface might remain so huge that they extremely compromise somewhat possible gains. Equally, in moderate climate conditions, the losses from evaporation reservoir remain comparatively small. For example, reservoirs evaporation from Volga River basin (where approximately 300 reservoirs of storage capacity which can reach over $1,000,000$ cubic meters) found a reduction of $3-5 \%$ of the Volga River runoff. Level of groundwater rise in the reservoir periphery as well as along the changes nearby the runoff mechanism generation in these areas. Steady river flow regime changes may happen due to a decreasing consequence of river's carrying capacity toward transporting sediments, particularly from above as well as in reservoirs. Sediment input reduction at the site of the dam decreases the channel of river slope as well as the bed sheer pressure, leading to falling flow velocities as well as river meandering development. The irrigation impact on water cycle is particu- 
larly revealing in dry areas, nevertheless it is likewise significant in areas with favorable climatic conditions where irrigation activities is of supplementary character. Water diversion of irrigation purposes resulting from ground or surface water resources alters the processes of natural hydrological. Common runoff as well as evaporation resulting from areas irrigated upsurge significantly. River basins irrigation where there is no additional method of supply frequently leading toward reduction of runoff in the outlet site. In several arid regions, a substantial increase in groundwater table could happen due to filtration of water from reservoirs, water distributing systems leakages, as well as defective irrigation technology. Such an increase can lead to plants waterlogging as well as soil development salinization.

Removal of surplus water from soils that is waterlogged, drainage systems are used in several world regions. The prime drainage effect remains the groundwater table lowering as well as extend the layer through soil that are unsaturated. As a consequence, evapotranspiration can be significantly reduced (by over $50 \%$ in some cases). The enhancement of hydraulic conditions from increase drainage flow velocities. After construction in the first years of a drainage system, the yearly increase runoff is 20 to $30 \%$. Particularly huge increase in runoff could be detected all through the months of low runoff in winter as well as summer. Flow acceleration likewise leads toward a remarkable flood peaks increase. After roughly 10 to 15 years, the drainage impact on runoff declines. Due to groundwater quality, which is generally higher than surface water, as well as its relative constant temperature, huge groundwater volumes remain extracted in some parts of the world for domestic, industrial as well as agricultural use (see Figure 4, $5,6 \& 7$ below) ${ }^{[1,5,18,27,34-36,40-44]}$.

When groundwater is taken from a confined aquifer beneath impermeable layers, groundwater table remains only somewhat impacted, as most contaminants originate from human activities such as industrial processes and mining, poor waste management, unsustainable farming practices, accidents ranging from small chemical spills to accidents at nuclear power plants, and the many effects of armed conflicts. Pollution knows no borders: contaminants are spread throughout terrestrial and aquatic ecosystems and many are distributed globally by atmospheric transport. Indeed, pollution tends to affects above and below ground biodiversity, both by reducing the number of organisms due to the toxicity caused by the contaminants, as well as by producing changes in communities, due to the replacement of more sensitive species by more pollution-tolerant ones. Low concentrations of contaminants often lead to adaptive strategies through changes in phys- iology and feeding behaviours. Changes in the activity of soil organisms can also occur, resulting in the alteration of biogeochemical cycles. Additionally, polluted soils in turn become a source of pollution for groundwater, through leaching of contaminants, and for fresh water and the marine environment, since contaminants can be transported off-site through wind and water erosion. All those changes can be gradual or remain inert until an inflexion point is reached and a severe degradation occurs. This triggers a chain of degradation processes in terrestrial and aquatic ecosystems that ultimately leads to the loss of ecosystem services (Figure 8).

In addition, in some river basins, the groundwater table frequently drops steeply, as well as this might decrease surface runoff as well as lower the level of small rivers. In several riverine regions, the groundwater extraction leads toward seawater disruption. With the water regime direct change of river basins through the control stream channel means, irrigation, drainage, as well as abstractions of groundwater, land use river basins changes can exert remarkable impact on the water cycle. The significances of the changes in land use might remain gradually exposed, as well as remain masked via climate variations. Nonetheless a vital hydrological transformation regime could happen. The utmost remarkable hydrological cycle distortions remain observed in urban areas, through natural land cover replacement with urban impermeable surface resulting in great decrease in infiltration as well as evapotranspiration. The precipitation runoff resulting from urban areas is usually produced as overland flow as well as quickly reaching into river drainage system. As a result, the amount of precipitation flood can increase many times, as well as the peaks of the hydrographs can be multiplied by 10 to $15^{[20,31,33]}$. Equally, transporting snow can result in a snowmelt runoff decrease. Because of infiltration reduction as well as groundwater abstractions for water supply in urban area ${ }^{[40,41]}$, groundwater table falls remain likewise observed in neighbourhood's urban areas. The agricultural effects as well as forestry practices on water cycle remain less apparent, as well as depend, to a remarkable extent, on the physiographic as well as climatic situations. It is clear that ploughing, particularly contour ploughing, often breaks up with overland flow as well as improves infiltration. Some distinct ploughing types can stretch the depression as well as storage detention on mild gradients from approximately 8 to $10 \mathrm{~mm}$ (under natural conditions) up to 30 to $40 \mathrm{~mm}$. Tillage as well as the action of plant root systems altering the upper soil layer structure as well as vertical permeability changes, nonetheless the water holding capacity. The vegetation cover extension as well as leaves area increases precipitation interception 


\section{QUALITY OF GROUNWATER}

\section{Condensatio}
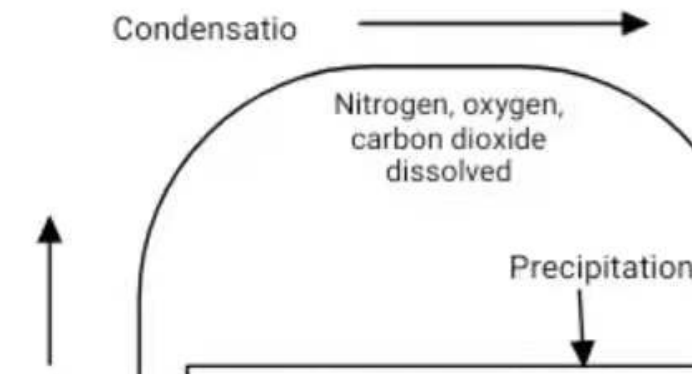

Temporary retention in mountain areas as soil water

1. $\mathrm{CO}_{2}$ dissolved in soil, $\mathrm{Ca}$, $\mathrm{Mg}, \mathrm{Na}$ bicarbonates added to water

2. $\mathrm{SO}_{4}$ dissolved in areas where oxidation of sulfides is occurring

3. Connate water or soluble compounds of marine sediments added

\section{Evaporation}

Chlorides and

Sulphates of sodium, magnesium, calcium, and potassium carried with water vapor

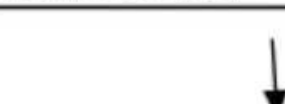
Runoff

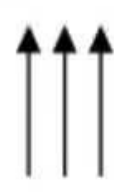

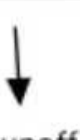

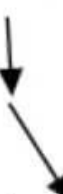
Atmosphere -
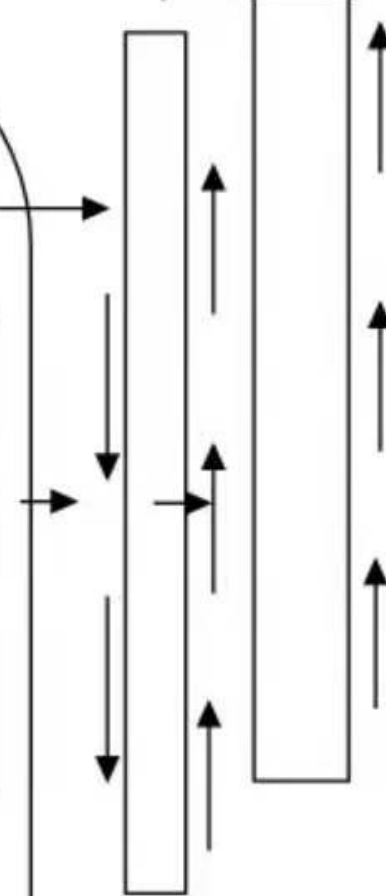

Evaporation ; mineral matter retained in soil

Transportation, mineral matter largely retained in soil, partly carried off in crop plants

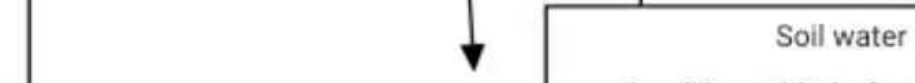

1. $\mathrm{CO}_{2}$ added forming carbonic acid

2. Reaction of soil minerals with carbonic acid to form soluble bicarbonates

3. Precipitation of colloidal iron, aluminum, and silica, of
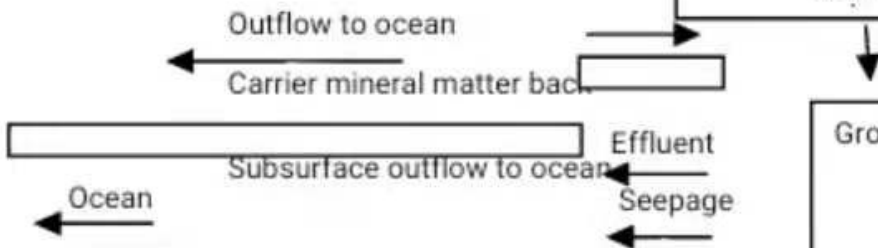

Groundwater

1. Cation exchange

2. Sulphate reduction by anaerobic bacteria substituting bicarbonate for

Figure 4. Geochemical cycle of surface water and groundwater (Adapted from David ${ }^{[45]}$ ) 


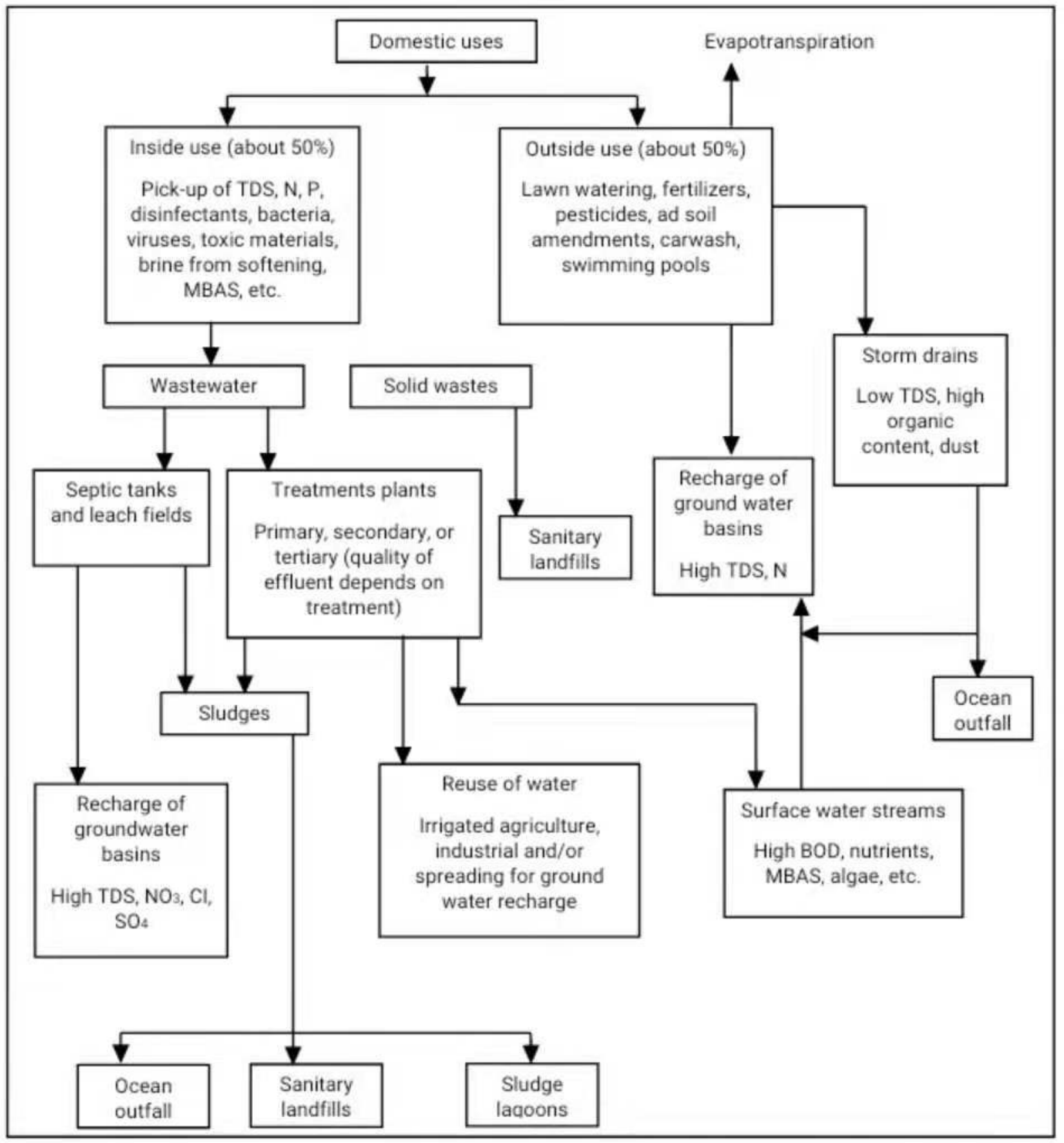

Figure 5. Domestic uses of water and their effects on water quality (Adapted from David, ${ }^{[45]}$ ) 


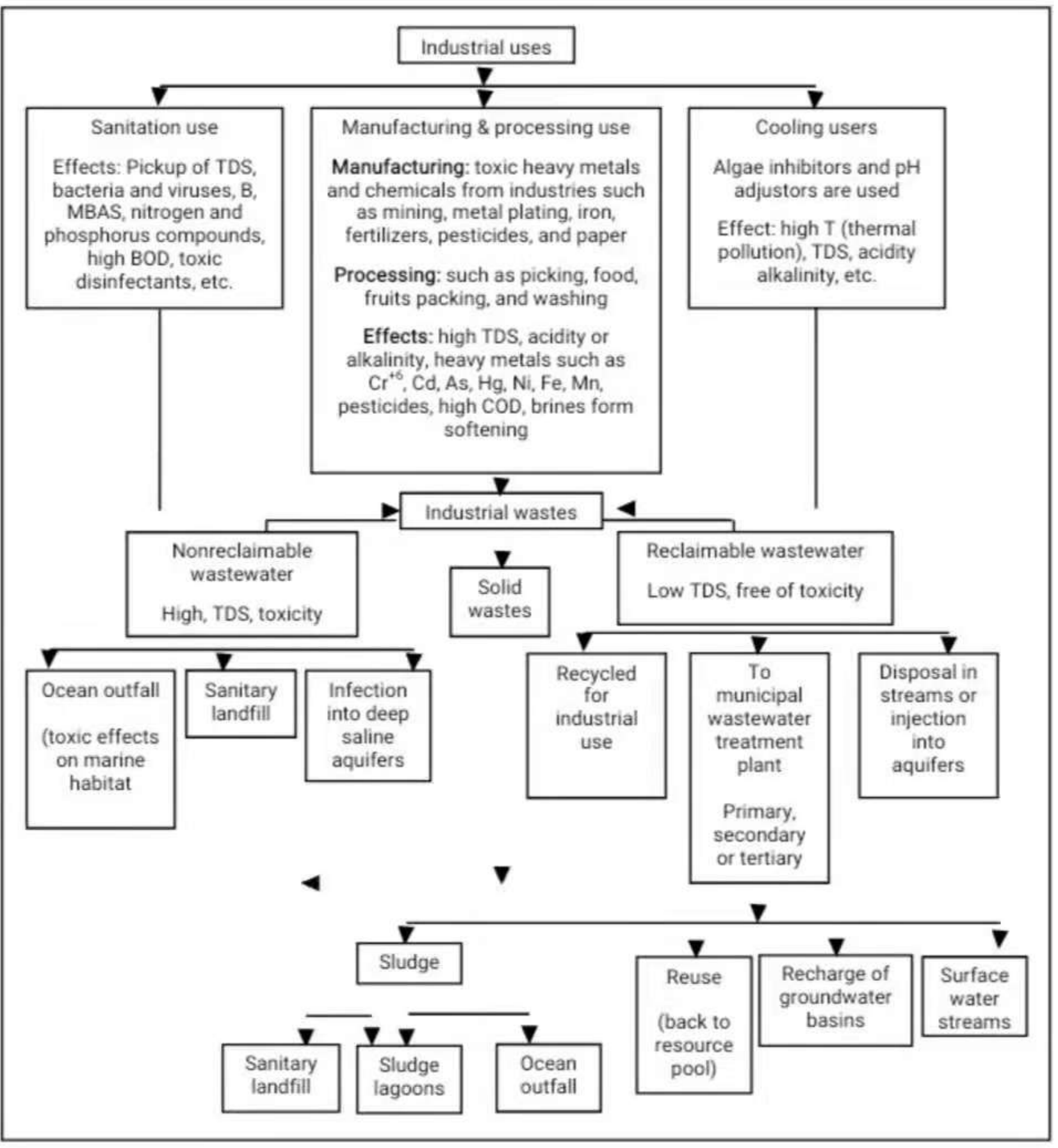

Figure 6. Industrial uses of water and their effects on water quality (Adapted from David ${ }^{[45]}$ ) 


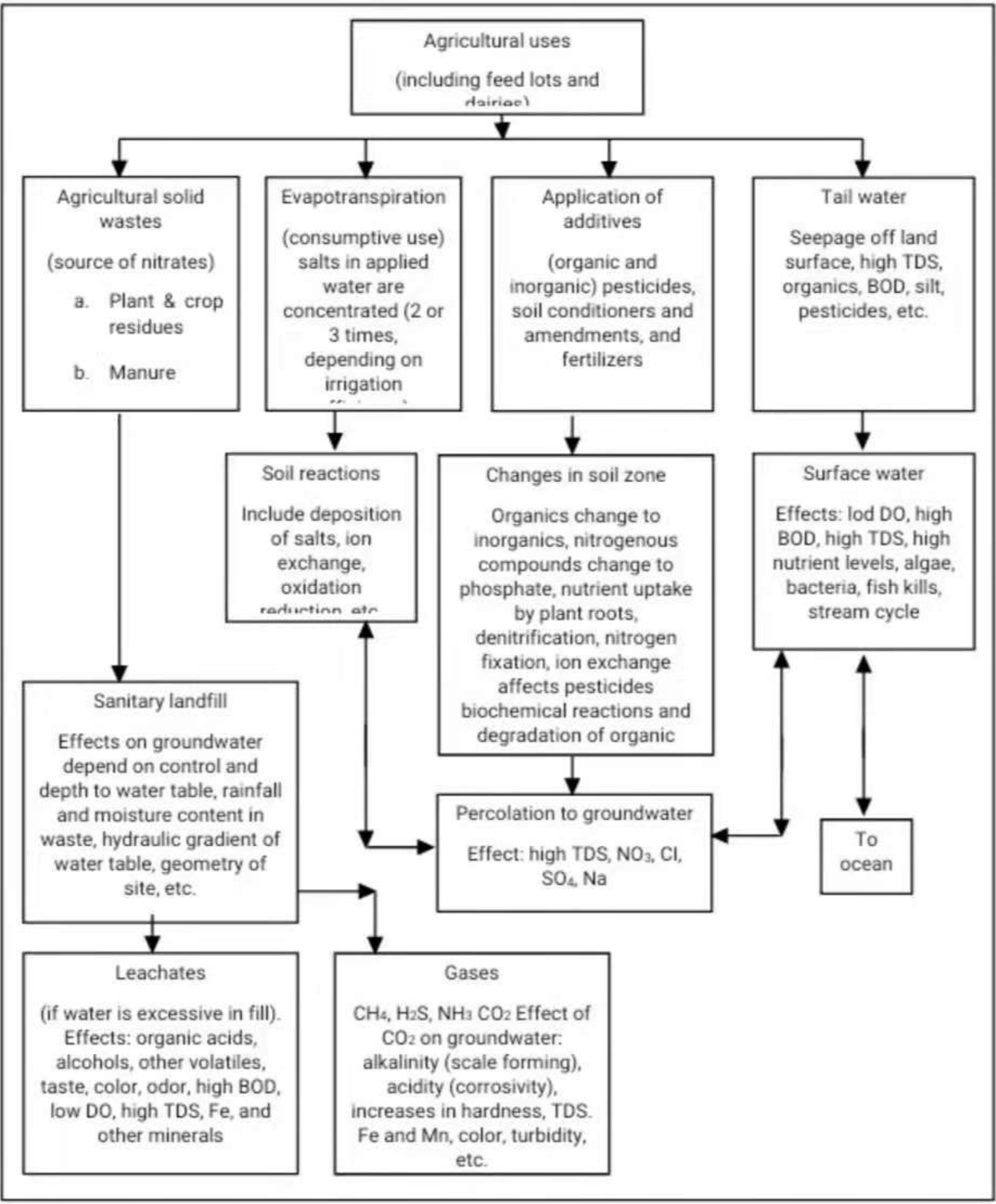

Figure 7. Agricultural uses of water and their effects on water quality (Adapted from David ${ }^{[45]}$ ). 


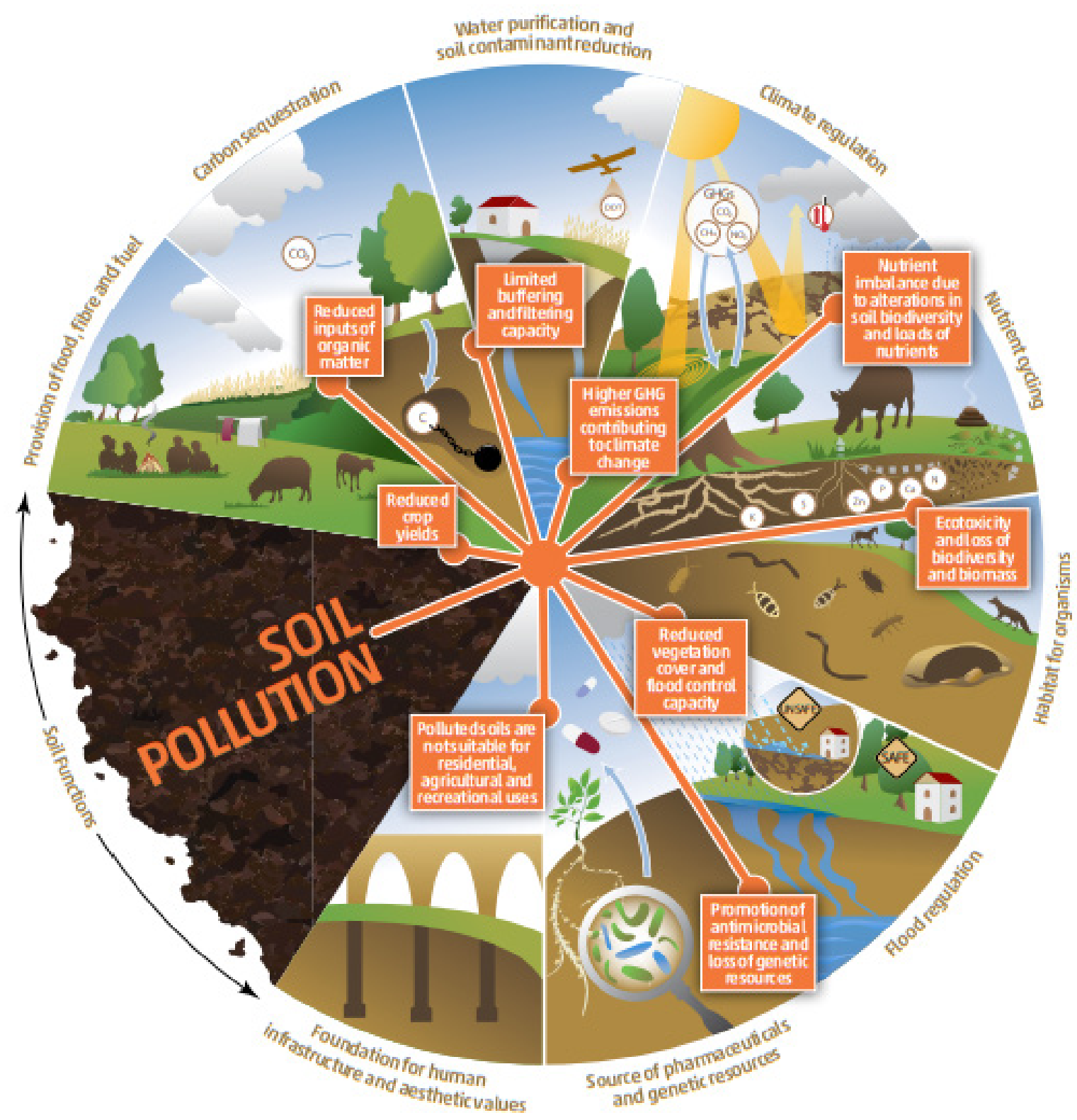

Figure 8. Soil pollution causes a cycle of degradation processes that leads to the reduction and ultimately to the loss of ecosystem services

Sources: Adapted from FAO and UNEP ${ }^{[46]}$

as well as evapotranspiration. Overland flow control of impenetrable permanent grasses on steeper gradients may decrease storm runoff resulting from small watersheds via 20 to $25 \%$. Of course, the relative impact of all these changes yearly as well as flood runoff remains determined through river basin as well as climate features. In arid regions (for instance, steppe zone), the 15 to $20 \%$ yearly runoff changes triggered through agricultural practice have remained fixed, as well as over different years such changes reached 30 to $40 \%$. Equally, in wet regions, particularly in forest as well as steppe zone in northern forest, the agricultural practices impact on runoff can be ignored. The results clearly show deforestation effects on water cycle of a river basin or increased transpiration as well as precipitation interception, which sequentially reduces total runoff volume. Deforestation decreases infiltration as well as improves overland flow conditions in the country. Accordingly, flooding as well as peak discharges might remarkably increase. Equally, forest soils with higher infiltration increases opportunity aimed at groundwater recharge, as well as small rivers flow tends to be especially more sustained, particularly to produce snowmelt runoff 
such as when forests sustain continuous flow through snowmelt delaying. Rising groundwater table as well as ground runoff increase might increase the low flow of medium as well as large-sized rivers. This effect frequently led to the deduction that forests upsurge runoff ${ }^{[3,6,7]}$. Though, thorough research observations on the representative as well as experimental basins don't regularly agree with such inferences. For instance, the outcomes of (15) fifteen individual watershed-scale experiments, including several forest cutting rates, conducted by the Coweeta Hydrologic Laboratory in Southern Appalachia throughout 50 years, show deforestation increased while afforestation decreased yearly as well as monthly runoff, nonetheless responses magnitude remained extremely variable. It recognised that the actual response from streamflow toward cutting of forest remained inversely proportional toward input of solar energy (according to the evapotranspiration index). The monthly alteration runoff is in line with the evapotranspiration changes. By the lowest flow, the regular monthly runoff was approximately $100 \%$ larger in clear-cut forest than without uncut forest. Clear cutting is less effective at the moment on flow during winter as well as early spring. Long-term research observations have likewise revealed the strong evidence of the volume of runoff on vegetal cover type. Hardwood conversion to pine decreased yearly runoff via $25 \mathrm{~cm}$ as well as produced important reductions of regular monthly runoff. Equally, deforestation has resulted to substantial upsurge in flooding. Comparable outcomes were also obtained in relation to the basis of analyzing data gotten in other physiographic contexts. Forest zone research carried out in European region of Russia have revealed that forest impact on evapotranspiration, as well as runoff remarkably depends on forest age. Cutting down old forest might not modify evaporation, as well as accumulation increase of snow might cause roughly growth of spring runoff. In several areas, forest cutting has led to a remarkable intensification in disastrous floods as well as also triggered severe soil erosion ${ }^{[2,3,6.7]}$. In addition, the process of urbanization often causes changes in groundwater levels as a result of decreased recharge and increased withdrawal. In rural areas water supplies are usually obtained from shallow wells, while most of the domestic wastewater is returned to the ground through cesspools or septic tanks. Thus, a quantitative balance in the hydrologic system remains. As population increase, many individual wells are abandoned in favour of deeper public wells. Later, with the introduction of sewer systems, storms water and wastewater typically discharge to a nearby surface water body. Thus, three conditions disrupt the subsurface hydrologic balance and produce decline in groundwater levels; i. Reduced groundwater recharge due to paved surface areas and storm servers.

ii. Increased groundwater discharge by pumping wells.

iii.Decreased groundwater recharge due to export of water collected by sanitary servers.

Here the above conditions have all been present leaching not only to a decline in water tables but also to groundwater pollution, seawater intrusion and reduced streamflow.

\section{Conclusions}

The COVID-19 crisis has reiterated the importance of biogeochemical cycles by highlighting the linkages between biogeochemical cycles and human health ${ }^{[47-}$ 49,53,54]. Human activity has degraded ecosystems as well as ecological barriers which would normally limit disease transfer ${ }^{[18,41-44]}$. As countries seek to build back better from the pandemic, biogeochemical cycles, biodiversity conservation and nature-based investment solutions is essential ${ }^{[50-52]}$. Thus, the carbon budget of the Earth is meticulously connected to the atmosphere, oceans as well as land and to the mass air movements round the planet. In the oceans, the surface water acts as the main site of exchange of carbon amongst atmosphere and ocean. The surface water's ability to absorb $\mathrm{CO}_{2}$ is overseen largely by $\mathrm{CO}_{2}$ reaction with the carbonate ion to create bicarbonates. The uptake of $\mathrm{CO}_{2}$ from the atmosphere by terrestrial ecosystems is governed by gross production (photosynthesis). Losses are a function of autotrophic and heterotrophic respiration; the latter being dominated by microbial decomposers. Human pour nitrogen dioxide into the atmosphere and nitrates into aquatic ecosystems. The major sources of nitrogen oxides are automobiles and power plants. Nitrogen dioxide is then converted through ultraviolet light in the direction of nitrogen monoxide as well as atomic oxygen. These substances react with hydrocarbons in the atmosphere to produce a number of pollutants, including ozone and PAN. Both PAN and ozone make up photochemical smog, a pollutant harmful to plants and animals. Excessive quantities of nitrates are added to aquatic ecosystems by improper use of nitrogen fertilizer on agricultural crops, by animal wastes, and by sewage effluents. Nitrogen oxides have also been implicated in forest decline. Thus, water is important to the milieu as well as is well-thought-out to be nature drivers. All studies relating to water remain concerned with portion of the water cycle. The occurrence as well as water availability is thoroughly associated with human advancement. Due to several activities of humans, the characteristics/ features of several water cycle components are experienc-

DOI: http://dx.doi.org/10.36956/rwae.v2i3.426 
ing changes, which can lead to long-term climate change. It is obligatory toward predicting the magnitude as well as extent of these variations so that vital ameliorative measures could be originated in time. Hence, the disturbances of the balance of biogeochemical cycle resulting from human activities hinders the achievement of many of the United Nations Sustainable Development Goals (SDGs), including those related to poverty elimination (SDG 1), zero hunger (SDG 2) and good health and wellbeing (SDG $3)$. Also, it hits the most vulnerable hardest, especially children and women (SDG 5). The supply of safe drinking water is threatened by the leaching of contaminants into groundwater and runoff (SDG 6). Furthermore, $\mathrm{CO}_{2}$ and $\mathrm{N}_{2} \mathrm{O}$ emissions accelerate climate change (SDG 13) and contribute to land degradation and loss of terrestrial (SDG 15 ) and aquatic (SDG 14) biodiversity, and decreased security and resilience of cities (SDG 11), among others. As the support for all terrestrial life is involved in the regulation and provision of many key ecosystem services that are essential to the environment and to human health and well-being. Thus, a transformative approach that is in line with the 2030 Agenda for Sustainable Development, which sets out to achieve socio-economic development, while conserving the environment is remarkable.

\section{Funding}

No specific grant was received for this study.

\section{Competing Interests}

We affirm that we have no conflict of interest that may be alleged as prejudicing the impartiality of the study reported. This researcher did not receive special assistance from government, not-for-profit sectors or commercial institutions.

\section{Consent}

All the authors announced that they had received written notice from the participants.

\section{Disclosure Statement}

The authors are not aware of any biases, affiliations, memberships, funding, or financial holdings that might be perceived as affecting the objectivity of this review.

\section{Acknowledgments}

I thank Dr. Henry Olawale Sawyerr, Dr. Clinton Ifeanyichukwu Ezekwe, Dr. Adedoyin Oluwatoyin Omidiji, Dr. Tonye Vivien Odubo and Mrs Raimi Aziba-anyam Gift as well as all anonymous reviewers, for feedback and discus- sions that helped to substantially improve this manuscript.

\section{References}

[1] Raimi Morufu Olalekan, Bilewu Olaolu Oyinlola, Adio Zulkarnaini Olalekan, Abdulrahman Halimat (2019) Women Contributions to Sustainable Environments in Nigeria. Journal of Scientific Research in Allied Sciences. 5(4), 35-51. ISSN NO. 2455-5800.

DOI: No. 10.26838/JUSRES.2019.5.4.104.

[2] Raimi M O, Suleiman R M, Odipe O E, Salami J T, Oshatunberu M, et al (2019). Women Role in Environmental Conservation and Development in Nigeria. Ecology \& Conservation Science; 1(2): Volume 1 Issue 2 - July 2019. https://juniperpublishers.com/ ecoa/pdf/ECOA.MS.ID.555558.pdf.

DOI: 10.19080/ECOA.2019.01.555558

[3] Olalekan RM, Omidiji AO, Williams EA, Christianah MB, Modupe O (2019). The roles of all tiers of government and development partners in environmental conservation of natural resource: a case study in Nigeria. MOJ Ecology \& Environmental Sciences 2019;4(3):114-121.

DOI: 10.15406/mojes.2019.04.00142.

[4] Okoyen E, Raimi M O, Omidiji A O, Ebuete A W (2020). Governing the Environmental Impact of Dredging: Consequences for Marine Biodiversity in the Niger Delta Region of Nigeria. Insights Mining Science and technology 2020; 2(3): 555586. https://juniperpublishers.com/imst/pdf/IMST. MS.ID.555586.pdf

DOI: 10.19080/IMST.2020.02.555586.

[5] Suleiman Romoke Monsurat, Raimi Morufu Olalekan and Sawyerr Henry Olawale (2019) A Deep Dive into the Review of National Environmental Standards and Regulations Enforcement Agency (NESREA) Act. International Research Journal of Applied Sciences. pISSN: 2663-5577, eISSN: 26635585. www.scirange.com. https://scirange.com/abstract/irjas.2019.108.125.

DOI: No. Irjas.2019.123.123.

[6] Raimi Morufu Olalekan, Tonye V. Odubo, Omidiji Adedoyin O, Oluwaseun E. Odipe (2018) Environmental Health and Climate Change in Nigeria. World Congress on Global Warming. Valencia, Spain. December 06-07, 2018.

[7] Morufu Olalekan Raimi, Tonye Vivien Odubo \& Adedoyin Oluwatoyin Omidiji (2021) Creating the Healthiest Nation: Climate Change and Environmental Health Impacts in Nigeria: A Narrative Review. Scholink Sustainability in Environment. ISSN 2470637X (Print) ISSN 2470-6388 (Online) Vol. 6, No. 
1, 2021 www.scholink.org/ojs/index.php/se. URL: http://dx.doi.org/10.22158/se.v6n1p61. http://www. scholink.org/ojs/index.php/se/article/view/3684.

[8] Ajayi Folajimi Ajibola, Raimi Morufu Olalekan, Steve-Awogbami Oluseyi Catherine, Adeniji Anthony Olusola, Adebayo Patrick Adekunle (2020) Policy Responses to Addressing the Issues of Environmental Health Impacts of Charcoal Factory in Nigeria: Necessity Today; Essentiality Tomorrow. Communication, Society and Media. Vol 3, No 3.

DOI: https://doi.org/10.22158/csm.v3n3p1. http://www. scholink.org/ojs/index.php/csm/article/view/2940.

[9] Ebuete Abinotami Williams, Raimi Morufu Olalekan, Ebuete Ibim Yarwamara \& Oshatunberu Modupe (2019) Renewable Energy Sources for the Present and Future: An Alternative Power Supply for Nigeria. Energy and Earth Science. Vol. 2, No. 2, 2019. URL: http://dx.doi.org/10.22158/ees.v2n2p18. http://www. scholink.org/ojs/index.php/ees/article/view/2124.

[10] Hussain Muhammad Isah, Morufu Olalekan Raimi, Henry Olawale Sawyerr (2021) Patterns of Chemical Pesticide Use and Determinants of Self-Reported Symptoms on Farmers Health: A Case Study in Kano State for Kura Local Government Area of Nigeria. Research on World Agricultural Economy. Vol 2, No. 1. DOI: http://dx.doi.org/10.36956/rwae.v2i1.342.

[11] Morufu Olalekan Raimi, Tonye Vivien Odubo, Ogah Alima, Henry Akpojubaro Efegbere, Abinotami Williams Ebuete (2021) Articulating the effect of Pesticides Use and Sustainable Development Goals (SDGs): The Science of Improving Lives through Decision Impacts. Research on World Agricultural Economy. Vol 2, No. 1.

DOI: http://dx.doi.org/10.36956/rwae.v2i1.347.

[12] Morufu Olalekan Raimi (2021). "Self-reported Symptoms on Farmers Health and Commonly Used Pesticides Related to Exposure in Kura, Kano State, Nigeria". Annals of Community Medicine \& Public Health. 1(1): 1002. http://www.remedypublications. com/open-access/self-reported-symptoms-on-farmers-health-and-commonly-used-pesticides-related-6595.pdf. http://www.remedypublications.com/annals-of-community-medicine-public-health-home.php.

[13] Isah, H. M., Sawyerr, H. O., Raimi, M. O., Bashir, B. G., Haladu, S. \& Odipe, O. E. (2020). Assessment of Commonly Used Pesticides and Frequency of Self-Reported Symptoms on Farmers Health in Kura, Kano State, Nigeria. Journal of Education and Learning Management (JELM), HolyKnight, vol. 1, 31-54. doi.org/10.46410/jelm.2020.1.1.05. https:// holyknight.co.uk/journals/jelm-articles/.
[14] Olalekan RM, Muhammad IH, Okoronkwo UL, Akopjubaro EH (2020). Assessment of safety practices and farmer's behaviors adopted when handling pesticides in rural Kano state, Nigeria. Arts \& Humanities Open Access Journal. 2020;4(5):191-201.

DOI: 10.15406/ahoaj.2020.04.00170.

[15] Isah Hussain Muhammad, Raimi Morufu Olalekan, Sawyerr Henry Olawale, Odipe Oluwaseun Emmanuel, Bashir Bala Getso, Suleiman Haladu (2020) Qualitative Adverse Health Experience Associated with Pesticides Usage among Farmers from Kura, Kano State, Nigeria. Merit Research Journal of Medicine and Medical Sciences (ISSN: 2354-323X) Vol. 8(8) pp. 432-447, August, 2020.

DOI: $10.5281 /$ zenodo.4008682. https://meritresearchjournals.org/mms/content/2020/August/ Isah\%20et\%20al.htm.

[16] Raimi Morufu Olalekan, Sawyerr Henry Olawale and Isah Hussain Muhammad (2020) Health risk exposure to cypermethrin: A case study of kano state, Nigeria. Journal of Agriculture. 7th International Conference on Public Healthcare and Epidemiology. September 14-15, 2020 | Tokyo, Japan.

[17] Asthana D. K and Asthana M (2007) A textbook of Environmental Studies for undergraduate Students (As per UGC Syllabus) S. Chand and Company ltd. Ram Nagar, New Delhi.

[18] Olalekan R. M, Dodeye E. O, Efegbere H. A, Odipe O. E. Deinkuro N. S, Babatunde A and Ochayi E. O (2020) Leaving No One Behind? Drinking-Water Challenge on the Rise in Niger Delta Region of Nigeria: A Review. Merit Research Journal of Environmental Science and Toxicology (ISSN: 2350-2266) Vol. 6(1): 031-049.

DOI: 10.5281/zenodo.3779288.

[19] Henry O. Sawyerr, Odipe E. Oluwaseun1, Olawale S. Asabi, Raimi M. Olalekan (2019) Bacteriological Assessment of Selected Hand Dug Wells in Students' Residential Area: A Case Study of Osun State College of Health Technology, Ilesa, Nigeria. Global Scientific Journal, Volume 7, Issue 1, January 2019, Online: ISSN 2320-9186. www.globalscientificjournal.com.

[20] Bhatti, J. S., van Kooten, G. C., Apps, M. J., Laird, L. D., Campbell, I. D., Campbell, C., Turetsky, M. R., Yu, Z., and Banfield, E (2003)., Carbon balance and climate change in boreal forests, in Towards Sustainable Management of the Boreal Forest, Burton, P.J., Messier, C., Smith, D.W., and Adamowicz, W.L., Eds., NRC Research Press, National Research Council of Canada, Ottawa, 2003, 799-855.

[21] Schimel, D. S (1995). Terrestrial ecosystems and the 
carbon cycle, Global Change Biol., 1, 77, 1995.

[22] Houghton, R. A (2003)., Revised estimates of the annual net flux of carbon to the atmosphere from changes in land use and land management 18502000, Tellus, 55B (2), 378, 2003.

[23] Schlesinger, W. H (1997)., Biogeochemistry: An Analysis of Global Change, 2nd ed., Academic Press, New York, 1997, 588.

[24] Morufu Raimi, Timothy Kayode Samson, Ajayi Bankole Sunday et al (2021). Air of Uncertainty from pollution profiteers: Status of ambient air quality of sawmill industry in Ilorin Metropolis, Kwara State, Nigeria, 25 February 2021, PREPRINT (Version 1) available at Research Square [https://doi. org/10.21203/rs.3.rs-270757/v1].

[25] Raimi Morufu Olalekan, Adio Zulkarnaini Olalekan, Odipe Oluwaseun Emmanuel, Timothy Kayode Samson, Ajayi Bankole Sunday \& Ogunleye Temitope Jide (2020) Impact of Sawmill Industry on Ambient Air Quality: A Case Study of Ilorin Metropolis, Kwara State, Nigeria. Energy and Earth Science Vol. 3, No. 1, 2020. URL: http://dx.doi.org/10.22158/ees. v3n1p1. www.scholink.org/ojs/index.php/ees ISSN 2578-1359 (Print) ISSN 2578-1367 (Online).

[26] Raimi Morufu Olalekan, Adeolu Adedotun Timothy, Enabulele Chris E, Awogbami Stephen Olalekan (2018) Assessment of Air Quality Indices and its Health Impacts in Ilorin Metropolis, Kwara State, Nigeria. Science Park Journals of Scientific Research and Impact Vol. 4(4), pp. 060-074, September 2018 ISSN 2315-5396.

DOI: $10.14412 /$ SRI2018.074.http://www.scienceparkjournals.org/sri/pdf/2018/September/Olalekan_ et_al.pdf. http://www.scienceparkjournals.org/sri/Content/2018/September/2018.htm.

[27] Raimi Morufu Olalekan (2019) $21^{\text {st }}$ Century Emerging Issues in Pollution Control. $6^{\text {th }}$ Global Summit and Expo on Pollution Control May 06-07, 2019 Amsterdam, Netherlands.

[28] Premoboere Edna Ateboh and Raimi Morufu Olalekan (2018). Corporate Civil Liability and Compensation Regime for Environmental Pollution in the Niger Delta. International Journal of Recent Advances in Multidisciplinary Research Vol. 05, Issue 06, pp. 3870-3893, June, 2018.

[29] Boden T. A, Marland G, Andres R. J (1995) Estimates of Global, Regional, and National Annual $\mathrm{CO}_{2}$ Emissions from Fossil-Fuel Burning, Hydraulic Cement Production, and Gas Flaring: 1950-1992 (Oak Ridge National Laboratory, U.S. Department of Energy, Oak Ridge, TN), Available at http://cdiac. esd.ornl.gov/epubs/ndp/ndp030/ndp0301.htm.

[30] Batjes H. Niels (2014) Total carbon and nitrogen in the soils of the world. British Society of Soil Science, European Journal of Soil Science, 65, 4-21.

[31] Houghton R. A, Hackler J. L (2002) in Trends: A Compendium of Data on Global Change (Carbon Dioxide Information Analysis Center, Oak Ridge National Laboratory, U.S. Department of Energy, Oak Ridge, TN), Available at http://cdiac.ornl.gov/trends/ landuse/houghton/houghton.html.

[32] Houghton, R. A (2000)., Interannual variability in the global carbon cycle, J. Geophys. Res., 105, 20121, 2000.

[33] Smith, S. V. et al (2001)., Budgets of soil erosion and deposition for sedimentary organic carbon across the conterminous U.S., Global Biogeochem. Cycles, 15, 697, 2001.

[34] Raimi Morufu Olalekan and Sabinus Chibuzor Ezugwu (2017) An Assessment of Trace Elements in Surface and Ground Water Quality in the Ebocha-Obrikom Oil and Gas Producing Area of Rivers State, Nigeria. International Journal for Scientific and Engineering Research (Ijser): Volume 8, Issue 6, July Edition. ISSN: 2229-5518.

[35] Morufu Raimi and Clinton Ezekwe (2017), Assessment of Trace Elements in Surface and Ground Water Quality (2017) LAP Lambert Academic Publishing. Mauritius. ISBN: 978-3-659-38813-2. www.omniscriptum.com.

[36] Olalekan, R. M., Omidiji, A. O., Nimisngha, D., Odipe, O. E. and Olalekan, A. S. (2018). Health Risk Assessment on Heavy Metals Ingestion through Groundwater Drinking Pathway for Residents in an Oil and Gas Producing Area of Rivers State, Nigeria. Open Journal of Yangtze Gas and Oil, 3, 191-206. https://doi.org/10.4236/ojogas.2018.33017.

[37] Odipe O. E, Raimi M. O, Suleiman F (2018). Assessment of Heavy Metals in Effluent Water Discharges from Textile Industry and River Water at Close Proximity: A Comparison of Two Textile Industries from Funtua and Zaria, North Western Nigeria. Madridge Journal of Agriculture and Environmental Sciences. 2018; 1(1): 1-6.

DOI: 10.18689/mjaes-1000101. https://madridge.org/ journal-of-agriculture-and-environmental-sciences/ mjaes-1000101.php.

[38] Henry Olawale Sawyerr, Morufu Olalekan Raimi, Adedotun Timothy Adeolu \& Oluwaseun Emmanuel Odipe (2019) Measures of Harm from Heavy Metal Pollution in Battery Technicians' Workshop within Ilorin Metropolis, Kwara State, Nigeria. Scholink Communication, Society and Media ISSN 2576-5388 
(Print) ISSN 2576-5396 (Online) Vol. 2, No. 2, 2019 www.scholink.org/ojs/index.php/csm.

DOI: https://doi.org/10.22158/csm.v2n2p73.

[39] Odubo Tonbra Robert and Raimi Morufu Olalekan (2019) Resettlement and Readjustment Patterns of Rural Dwellers During and After Flood Disasters in Bayelsa State Nigeria. British Journal of Environmental Sciences Vol .7, No .3, Pp. 45-52, July 2019. www.eajournals.org.

[40] Raimi Morufu Olalekan, Omidiji Adedoyin O, Adeolu Timothy Adedotun, Odipe Oluwaseun Emmanuel and Babatunde Anu (2019) An Analysis of Bayelsa State Water Challenges on the Rise and Its Possible Solutions. Acta Scientific Agriculture 3.8 (2019): 110-125.

DOI: 10.31080/ASAG.2019.03.0572.

[41] Olalekan RM, Adedoyin OO, Ayibatonbira A, et al (2019). "Digging deeper" evidence on water crisis and its solution in Nigeria for Bayelsa state: a study of current scenario. International Journal of Hydrology. 2019;3(4):244-257.

DOI: 10.15406/ijh.2019.03.00187.

[42] Olalekan R. M, Vivien O. T, Adedoyin O. O, et al. (2018). The sources of water supply, sanitation facilities and hygiene practices in oil producing communities in central senatorial district of Bayelsa state, Nigeria. MOJ Public Health. 2018;7(6):337-345.

DOI: 10.15406/mojph.2018.07.00265.

[43] Raimi, M. O, Pigha, Tarilayun K and Ochayi, E. O (2017) Water-Related Problems and Health Conditions in the Oil Producing Communities in Central Senatorial District of Bayelsa State. Imperial Journal of Interdisciplinary Research (IJIR) Vol-3, Issue-6, ISSN: 2454-1362.

[44] Raimi M. O, Abdulraheem A. F, Major Iteimowei, Odipe O. E, Isa H. M, Onyeche Chinwendu (2019). The Sources of Water Supply, Sanitation Facilities and Hygiene Practices in an Island Community: Amassoma, Bayelsa State, Nigeria. Public Health Open Access 2019, 3(1): 000134. ISSN: 2578-5001. DOI: $10.23880 /$ phoa-16000134.

[45] David Keith Todd (2006) Groundwater Hydrology. Second Edition. John Wiley and Sons, inc.

[46] FAO and UNEP. (2021). Global assessment of soil pollution - Summary for policy makers. Rome, FAO. https://doi.org/10.4060/cb4827en.

[47] Raimi Morufu Olalekan, Emeka Chisom Lucky, Ebikapaye Okoyen, Angalabiri Clement, Christopher Ogbointuwe, Atoyebi Babatunde (2021) COVID-19 Decision Impacts: Vaccine Hesitancy, its Barriers and Impact Studies: Taking Bayelsa State as an Example., 27 May 2021, PREPRINT (Version 1) available at Research Square [https://doi.org/10.21203/ rs.3.rs-566532/v1].

[48] Morufu Olalekan Raimi, Aziba-anyam Gift Raimi, Teddy Charles Adias (2021). Evidence-based Environmental and Public Health Practices to Respond to the COVID-19 Crisis, 07 May 2021, PREPRINT (Version 1) available at Research Square [https://doi. org/10.21203/rs.3.rs-504983/v1] https://europepmc.org/ article/PPRID/PPR335534; EMSID:EMS123969.

[49] Morufu Olalekan Raimi, Ebikapaye Okoyen, Tuebi Moses, Aziba-anyam Gift Raimi, Adedoyin Oluwatoyin Omidiji, Aishat Funmilayo Abdulraheem, Mariam Oluwakemi Raimi, Beatrice Oka Joseph (2021) Do Weak Institutions Prolong Crises? [\#ENDSARs] in the Light of the Challenges and opportunities beyond COVID-19 Pandemic and the Next Normal in Nigeria. Communication, Society and Media. ISSN 2576-5388 (Print) ISSN 2576-5396 (Online) Vol. 4, No. 2,

DOI: https://doi.org/10.22158/csm.v4n2p1. http://www. scholink.org/ojs/index.php/csm/article/view/3790.

[50] Raimi Morufu Olalekan \& Raimi Aziba-anyam Gift (2020). The Toughest Triage in Decision Impacts: Rethinking Scientific Evidence for Environmental and Human Health Action in the Times of Concomitant Global Crises. CPQ Medicine, 11(1), 01-05.

[51] Raimi Morufu Olalekan, Moses Tuebi, Okoyen Ebikapaye, Sawyerr Henry Olawale, Joseph Beatrice Oka, Oyinlola Bilewu Olaolu (2020) "A Beacon for Dark Times: Rethinking Scientific Evidence for Environmental and Public Health Action in the Coronavirus Diseases 2019 Era" Medical and Research Microbiology, Vol. 1, Issues 3.

[52] Samson T.K., Ogunlaran O.M., Raimi O.M. (2020); A Predictive Model for Confirmed Cases of COVID-19 in Nigeria. European Journal of Applied Sciences, Volume 8, No 4, Aug 2020;pp:1-10. DOI: 10.14738/aivp.84.8705.

DOI: https://doi.org/10.14738/aivp.84.8705.

[53] Gift RA, Olalekan RM, Owobi OE, Oluwakemi RM, Anu B, Funmilayo AA (2020). Nigerians crying for availability of electricity and water: a key driver to life coping measures for deepening stay at home inclusion to slow covid-19 spread. Open Access Journal of Science. 2020;4(3):69-80.

DOI: 10.15406/oajs.2020.04.00155.

[54] Gift R A, Olalekan RM (2020). Access to electricity and water in Nigeria: a panacea to slow the spread of Covid-19. Open Access J Sci. 2020;4(2):34.

DOI: 10.15406/oajs.2020.04.00148. https://medcrave.com/index.php?/articles/det/21409/. 